\title{
Characterization of genes involved in sumoylation during embryogenesis in rainbow trout (Oncorhynchus mykiss)
}

Xiaowei Zang

West Virginia University

Follow this and additional works at: https://researchrepository.wvu.edu/etd

\section{Recommended Citation}

Zang, Xiaowei, "Characterization of genes involved in sumoylation during embryogenesis in rainbow trout (Oncorhynchus mykiss)" (2013). Graduate Theses, Dissertations, and Problem Reports. 3621.

https://researchrepository.wvu.edu/etd/3621

This Thesis is protected by copyright and/or related rights. It has been brought to you by the The Research Repository @ WVU with permission from the rights-holder(s). You are free to use this Thesis in any way that is permitted by the copyright and related rights legislation that applies to your use. For other uses you must obtain permission from the rights-holder(s) directly, unless additional rights are indicated by a Creative Commons license in the record and/ or on the work itself. This Thesis has been accepted for inclusion in WVU Graduate Theses, Dissertations, and Problem Reports collection by an authorized administrator of The Research Repository @ WVU. For more information, please contact researchrepository@mail.wvu.edu. 


\title{
Characterization of Genes Involved in SUMOylation during Embryogenesis in Rainbow Trout (Oncorhynchus mykiss)
}

\author{
Xiaowei Zang
}

Thesis submitted to the

Davis College of Agriculture, Natural Resources and Design at West Virginia University in partial fulfillment of the requirements for the degree of

\author{
Master of Science \\ in \\ Genetics and Developmental Biology
}

\author{
Jianbo Yao, Ph.D., Chair \\ Kenneth P. Blemings, Ph.D. \\ Vagner A. Benedito, Ph.D. \\ Division of Plant \& Soil Sciences
}

Morgantown, West Virginia

2013

Keywords: SUMOylation, SUMO, embryogenesis, rainbow trout 


\title{
ABSTRACT \\ Characterization of Genes Involved in SUMOylation during Embryogenesis in Rainbow Trout (Oncorhynchus mykiss)
}

\begin{abstract}
Xiaowei Zang
SUMOylation is the post-translational modification of proteins by the addition of the small ubiquitin-like modifier (SUMO), which plays an important role in various cellular processes. It has been reported that SUMO and its related proteins are important in diverse reproductive functions such as ovulation, gametogenesis, and embryogenesis. Modification of target proteins by SUMO is an ATP-dependent enzymatic cascade involving three key enzymes: E1 activating enzyme (the heterodimer SAE1-SAE2), E2 conjugating enzyme (UBC9) and several E3 ligating enzymes (PIAS, RanBP2/Nup358 and Pc2). The objectives of this study were to characterize the genes involved in SUMOylation and determine their expression profiles during embryogenesis in rainbow trout. Through database analysis, ten Sumo related genes, which include Sumo1, Sumo2, Sumo3, Sae1, Sae2, Ubc9, Pias1, Pias4, Cbx4, and Nse2, were identified. Analysis of protein sequences of SUMO1 and UBC9, the key components in the pathway, revealed that they are highly conserved among human, mice, rat, cattle, pig, chicken, Xenopus, zebrafish and rainbow trout species. The expression profiles of the Sumo related genes during embryonic development in rainbow trout were analyzed by quantitative real time PCR using cDNAs derived from unfertilized eggs and embryos of 17 different developmental stages (0h, 3h, 7.5h, 11.5h, 13.5h, 18h, 27h, 34h, 2d, 3d, 4d, 5d, 6d, 8d, 10d, 12d, 16d and 25d post fertilization). The expression of Sumo3, Ubc9, Pias4, and Nse2 genes showed similar patterns, being low in unfertilized eggs and increasing gradually in early embryos until $18 \mathrm{~h}$ post fertilization followed by a gradual decrease in embryos after $18 \mathrm{~h}$ post fertilization; both Sumol and Sumo2 genes were highly expressed during maternal to zygotic transition (3d-5d post fertilization); while Sae1, Sae2, Piasl, and Cbx4 were expressed constitutively at steady-state levels throughout embryogenesis. The data indicate that the expression of Sumo related genes are dynamically regulated during the embryonic development in rainbow trout. To better understand how SUMO modification regulates embryonic development, two oocyte specific factors, FIGLA and LHX8, were studied for their interactions with SUMO. Under the experimental conditions used in the study, no apparent interactions of FIGLA or LHX8 with SUMO were detected. The study represents the first attempt to characterize genes involved in SUMOylation in rainbow trout. Further studies to understand the role of SUMOylation in controlling early embryogenesis may ultimately lead to the development of molecular markers for egg quality and embryonic development potential in rainbow trout.
\end{abstract}




\section{Acknowledgements}

Foremost, I would like to express my sincere gratitude to the chair of my advisory committee Dr. Jianbo Yao, for the continuous support of my master study and research, for his patience, motivation, encouragement, and immense knowledge. His guidance helped me in all the time of research and writing of this thesis and I truly cherish it.

I acknowledge the support by my thesis committee members Dr. Kenneth P. Blemings and Dr. Vagner A. Benedito for their enthusiasm on teaching and insightful comments on my thesis. Certainly their suggestions have made me a better speaker, writer and thinker.

I would like to thank my colleagues in the lab, Dr. Ma, Lei, Liyuan, Jackie, Jay, Jian, and Prasanthi, for the stimulating discussions, for the friendly lab environment, and for all the fun we have had in the past year.

I would also like to thank my friends in Morgantown, Lina, Ge, Yishu, Haiyang, Yuan, and my boyfriend Jay, for all the good days and bad days being there with me.

Last but not the least, I would like to thank my family, mom, dad, grandparents, aunties, uncles and cousins for supporting me spiritually throughout my life. I wish I could show them just how much I love and appreciate them. 


\section{Dedication}

To Lao ba and Lao ma 


\section{Table of Contents}

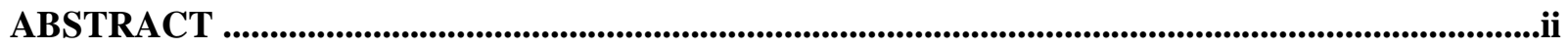

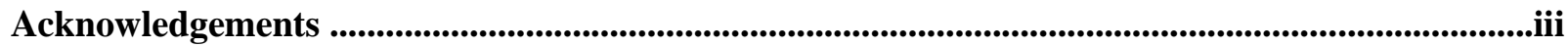

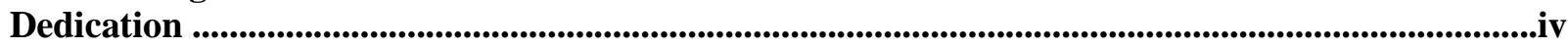

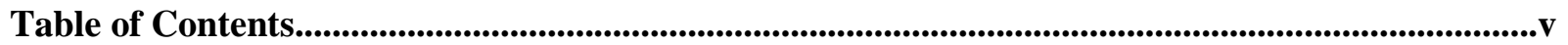

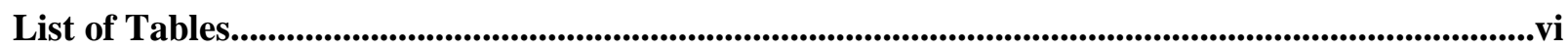

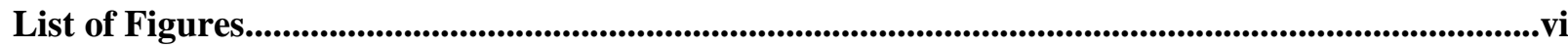

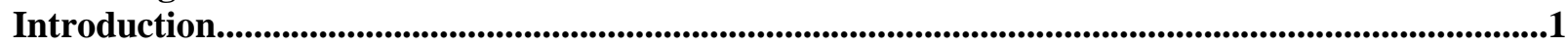

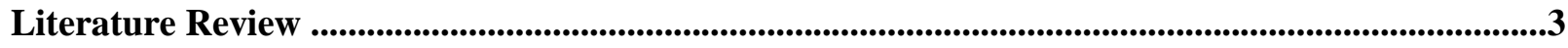

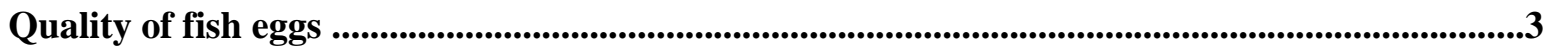

Oocyte-specific genes .......................................................................................................................................3

Embryonic development (Embryogenesis)................................................................................................5

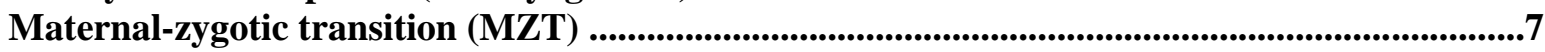

Small Ubiquitin Modifier (SUMO) .....................................................................................................7

SUMOylation .........................................................................................................................................................9

SUMO modification in reproductive function .......................................................................................11

Objectives of the Study ...............................................................................................................................................13

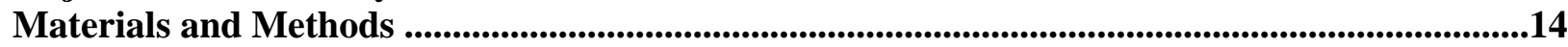

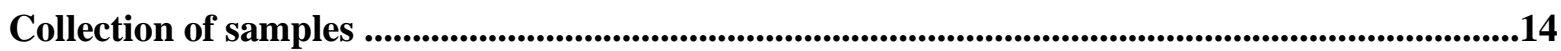

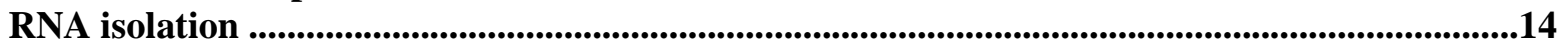

Treatment of RNA sample with DNase ........................................................................................................14

Reverse-Transcription Polymerase Chain Reaction (RT-PCR) .......................................................15

Quantitative real-time polymerase chain reaction (qPCR) and statistical anaylsis......................16

Analysis of protein sequences..................................................................................................................16

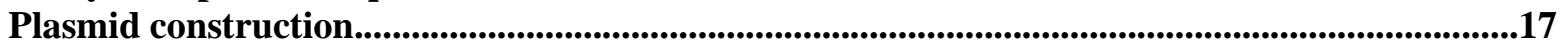

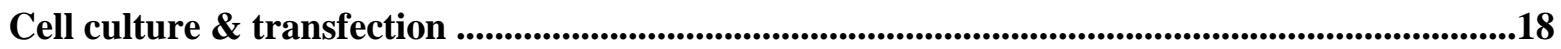

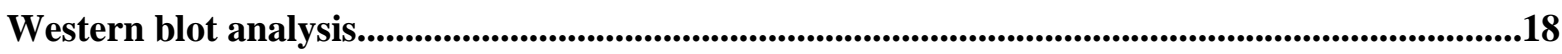

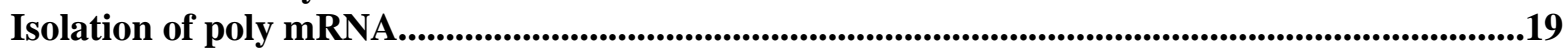

Construction of cDNA library for yeast two-hybridization..................................................................19

Transformation of cDNA library into pGADT7 vector..............................................................................20

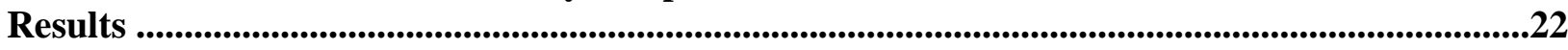

Identification of cDNA sequences for Sumo related genes in rainbow trout....................................22

Expression of genes involved in SUMOylation pathway during embryogenesis.............................22

Tissue distribution profile of $S u m o 1$ and $U b c 9$..................................................................................23

Identification of protein interactions between SUMO1 and FIGLA or LHX8.............................23

Construction of an oocyte cDNA library in pGADT7-Rec vector for yeast two

hybridization......................................................................................................................................................24

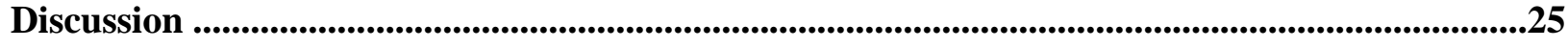

Tables and Figures ...................................................................................................................................29

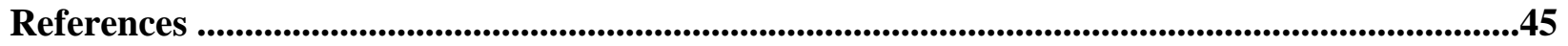




\section{List of Tables}

Table 1. Stages of early development in zebrafish..............................................................................6

Table 2. Genes involved in SUMOylation pathway of rainbow trout identified from

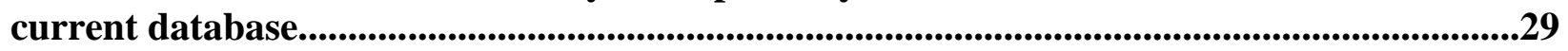

Table 3. GenBank or Gene Index (TC) number and sequence information for Sumo related genes in rainbow trout......................................................................................................................30

Table 4. Primers used in the study..........................................................................................................31

\section{List of Figures}

Figure 1. SUMOylation pathway: activation, conjugation and deconjugation.

Figure 2. Comparison of rainbow trout SUMO1 and UBC9 amino acid sequences with homologous sequences from other species by ClustalW2 software.

Figure 3. Neighbor joining phylogenetic tree of SUMO1 and UBC9 proteins among different species.

Figure 4. mRNA expression of SUMO paralogs during embryogenesis.

Figure 5. mRNA expression of SUMO activating and conjugating enzymes during embryogenesis.

Figure 6. mRNA expression of SUMO ligases during embryogenesis.

Figure 7. Tissue distribution of Sumo1 and $U b c 9$ mRNA analyzed by quantitative real-time PCR

Figure 8. FIGLA does not interact with SUMO1 in HEK293 cells.........................................42

Figure 9. LHX8 does not interact with SUMO1 in HEK293 cells................................................43

Figure 10. Analysis of oocyte cDNA library quality by PCR amplification of $U b c$, Figla, and Lhx8 genes. 


\section{Introduction}

Rainbow trout is one of the most important cold-water fish species in the USA due to its significance as a research model, in sports and food industry. Use of rainbow trout as a research model has been reported in various fields including cancer, toxicology and nutrition (Thorgaard et al., 2002). Many environmental and biological factors are known to affect the ability of an egg to produce a viable embryo (Brooks et al., 1997; Kjorsvik et al., 1990). These factors defining the developmental competence of an egg are highly variable, which can be a serious problem in the fish farming industry, especially for intensively cultured species, such as rainbow trout. Understanding these variations would be of great economic importance in hatcheries to address the increased demand of aquaculture products with lower production costs (Lee 2003). However, the mechanisms by which these factors trigger the loss of egg quality are largely unknown. Maternal and paternal mRNA transcripts are known to be essential for the development of a healthy embryo (Brooks et al., 1997). To date, several oocyte-specific maternal effect genes have been identified that include maternal antigen that embryos require (Mater) (Tong et al., 2000), zygote arrest 1 (Zarl) (Wu et al., 2003), and nucleoplasmin 2 (Npm2) (Burns et al., 2003). Other oocyte-specific genes that are potentially important for early embryonic development include Factor in the germline alpha (Figla) and LIM homeobox protein 8 (Lhx8); both of them are essential factors required for normal follicullogenesis (Soyal, 2000; Choi et al., 2008; Pangas et al., 2006).

Post-translational modifications are essential for certain proteins for their biological activities. SUMOylation is one of the post-translational modifications involving addition of the small ubiquitin-like modifier (SUMO), which plays an important role in various cellular 
processes. Modification of target proteins by SUMO is an ATP-dependent enzymatic process involving three key enzymes: E1 activating enzyme (the heterodimer SAE1-SAE2), E2 conjugating enzyme (UBC9) and several E3 ligating enzymes (PIAS, RanBP2/Nup358 and Pc2) (Johnson, 2004). It has been reported that SUMO and its related proteins are important in diverse reproductive functions such as ovulation, gametogenesis, and embryogenesis (Broday et al., 2004; Shao et al., 2004; Yuan et al., 2010). Previous studies have shown that octamer-binding transcription factor 4 (OCT4), an oocyte-specific maternal factor, is a target for SUMO modification and that SUMOylation enhances OCT4 stability, DNA binding activity, and transactivation (Wei et al., 2007).

As an initial step towards understanding the role of SUMOylation in controlling early embryogenesis in rainbow trout, the present study was carried out to identify Sumo-related genes and analyze their expression profiles during embryonic development in rainbow trout. Additional experiments were performed to determine whether FIGLA and LHX8 are SUMOylated. 


\section{Literature Review}

\section{Quality of fish eggs}

Many environmental and biological factors are known to affect the ability of a fish egg to produce a viable embryo, including paternal genes, pollution, quality of water (bacteria, temperature, oxygen content, etc.) and diet (Brooks et al., 1997; Kjorsvik et al., 1990). However, the mechanisms by which these factors alter egg quality are largely unknown. In fish, accumulation of maternal transcripts and proteins, which occurs mostly at late stages of oocyte maturation, is accompanied by vitellogenesis, a process characterized by hepatic production and massive deposition of yolk lipoproteins within the oocytes, providing the nutritional reserves necessary for embryogenesis (Tyler, 1996). Genes involved in vitellogenesis, as well as in the utilization of these reserves during early development, are essential for normal embryonic development in fish. Previous studies have suggested that yolk proteins, which are mainly composed of two lipoproteins called lipovitellins and phosphoproteins, may be used as genetic markers for egg quality (Brooks et al., 1997). However, studies on genes controlling egg quality in fish are limited.

\section{Oocyte-specific genes}

Studies in mice and other species have demonstrated the importance of oocyte-specific genes in folliculogenesis, fertilization and early embryonic development (Zheng and Dean, 2007). Key oocyte-specific genes known to be vital in folliculogenesis include factor in the germline alpha (Figla) (Soyal et al., 2000), growth differentiation factor 9 (Gdf9), LIM homeobox 8 (Lhx8) and bone morphogenetic protein 15 (Bmp15) (Choi et al., 2008). The essential roles of these 
genes in follicular development have been demonstrated primarily by their targeted deletion in mice and molecular genetic approaches in other species (Dong et al., 1996; Galloway et al., 2000; Soyal et al., 2000; Yan et al., 2001). Oocyte-expressed genes known to be essential for initial embryonic development include Mater (Tong et al., 2000), Zarl (Wu et al., 2003) and Npm2 (Burns et al., 2003). Despite these discoveries, our overall understanding of genes involved in oocyte development and regulation of early embryonic development is far from complete, particularly in fish species.

Figla encodes a germ-cell specific basic-helix-loop-helix (bHLH) transcription factor (Liang et al., 1997) and it is a major regulator of multiple oocyte specific genes, including zona pellucida protein genes $(Z p 1, Z p 2$ and $Z p 3)$ which are essential for early embryonic survival (Liang et al., 1997). Figla knockout in female mice appears to have normal embryonic gonadogenesis, with abnormal reduction in oocyte numbers resulting in smaller ovaries and eventually infertility. Contrary to females, knockout in male mice have normal fertility. These observations indicate that Figla plays a key regulatory role in oogenesis (Soyal et al., 2000). Expression of Figla is critical not only for activation of oocyte-associated genes but also for repression of sperm-associated genes during postnatal oogenesis (Hu et al., 2010). Therefore, Figla is a critical transcriptional regulator sustaining transcription of target genes in folliculogenesis. However, the molecular role of Figla during early embryogenesis is yet to be understood.

LHX8 is a member of the homeobox protein family that participates in tissue differentiation during ontogenesis (Kitanaka et al., 1998). The superfamily includes protein kinases, GTPaseactivation factors, and transcription factors, which are essential to intracellular signaling and cellular architecture (Dawid, 1998; Hunter and Rhodes, 2005). LHX8 contains two LIM homeo 
domains and is expressed from embryonic day 18.5 (E18.5) throughout folliculogenesis in mice (Jagarlamudi and Rajkovic, 2012) with its expression in the maxillary and mandibular processes and ventral forebrain during embryonic development in mice (Matsumoto et al., 1996; Grigoriou et al., 1998). Similar to Figla, Lhx8 knockout mice exhibit infertility due to oocyte depletion along with repression of multiple germ-cell specific genes, such as Figla and Bmp15 (Choi et al., 2008; Pangas et al., 2006). Recent studies in Xenopus suggest that loss of Lhx8, together with Msh homeobox 2 (Msx2) and retinoic acid results in decreased cell proliferation and failure to form the frontonasal prominence (Kennedy and Dickinson, 2012). However, the exact function of Lhx8 in early embryonic development has not been fully discerned.

\section{Embryonic development (Embryogenesis)}

Embryonic development (embryogenesis) is a process that starts with fertilization of the egg by sperm to form a zygote, followed by development of the embryo and eventually into a fetus. The developmental stages of zebrafish embryo, based on morphological features, were zygote $\left(0-{ }^{3} / 4\right.$ hours post fertilization), cleavage $\left(3 / 4-2{ }^{1} / 4 \mathrm{hpf}\right)$, blastula $\left(21_{4}-5 \frac{1}{4} \mathrm{hpf}\right)$, gastrula ( $5^{1} / 4^{-10}$ hpf), segmentation (10-24 hpf), pharyngula (24-48 hpf), to hatching (48-72 hpf) (Kimmel et al., 2005) (Table 1). Cleavage of the zygote after fertilization (the newly fertilized egg with one-cell), begins with two-cell stage and continues to 64-cell stage without significant increase in cell size. Division further to 128-cells into a ball-like shape is the blastula stage until the onset of epiboly, a characteristic of gastrula. Epiboly is the thinning and spreading of a multilayered sheet of cells, to form a cover over the embryo during gastrulation (Gilbert, 2003). Cell cycle lengthening marks the maternal-zygotic transition (MZT) of the blastula stage where maternal transcripts are degraded and zygotic genes activated (Schier, 2007). Formation of the 
embryonic axis defines the end of the gastrula period followed by morphogenetic movement, the segmentation period, where the somites and neuromere develop until the tail appears. Then the body axis is straightened and fin development begins in the pharyngula period. The last stage in embryogenesis is hatching where the rapid morphogenesis is complete, transforming into larvae 3 days after fertilization regardless if they have hatched or not (Kimmel, 2007).

Table 1. Stages of early development in zebrafish (Kimmel et al., 2005).

\begin{tabular}{|c|c|c|}
\hline Period & $\begin{array}{l}\text { Hours post } \\
\text { fertilization }\end{array}$ & Description \\
\hline Zygote & 0 & $\begin{array}{l}\text { The newly fertilized egg through the completion of the first } \\
\text { zygotic cell cycle }\end{array}$ \\
\hline Cleavage & $3 / 4$ & Cell cycles 2 through 7 occur rapidly and synchronously \\
\hline Blastula & $21 / 4$ & $\begin{array}{l}\text { Rapid, metasynchronous cell cycles give way to lengthened, } \\
\text { asynchronous ones at the midblastula transition; epiboly then } \\
\text { begins }\end{array}$ \\
\hline Gastrula & $51 / 4$ & $\begin{array}{l}\text { Morphogenetic movements of involution, convergence, and } \\
\text { extension form the epiblast, hypoblast, and embryonic axis; } \\
\text { through the end of epiboly }\end{array}$ \\
\hline Segmentation & 10 & $\begin{array}{l}\text { Somites, pharyngeal arch primordia, and neuromeres develop; } \\
\text { primary organogenesis; earliest movements; the tail appears }\end{array}$ \\
\hline Pharyngula & 24 & $\begin{array}{l}\text { Phylotypic-stage embryo; body axis straightens from its early } \\
\text { curvature about the yolk sac; circulation, pigmentation, and } \\
\text { tins begin development }\end{array}$ \\
\hline Hatching & 48 & $\begin{array}{l}\text { Completion of rapid morphogenesis of primary organ systems; } \\
\text { cartilage development in head and pectoral tin; hatching occurs } \\
\text { asynchronously }\end{array}$ \\
\hline Early larva & 72 & $\begin{array}{l}\text { Swim bladder inflates; food-seeking and active avoidance } \\
\text { behaviors }\end{array}$ \\
\hline
\end{tabular}




\section{Maternal-zygotic transition (MZT)}

Maternal-zygotic transition (MZT) is the stage at which the zygote switches to its own transcriptional machinery from its dependence on maternal RNA. After fertilization, maternal RNAs and proteins deposited by the mother into the egg drive early embryonic development while the newly formed embryo is transcriptionally inactive. During the transition, maternal RNAs are degraded from one-cell stage to blastula and gastrula stages, while zygotic genes start to be transcribed after blastula and gastrula stages (Schier, 2007). Previous studies in Drosophila provided evidence of the involvement of certain regulatory factors that recognize sequences in the 3' untranslated region (UTR) of maternal transcripts and mediate their degradation (Tadros and Lipshitz, 2005). Later studies in Xenopus and zebrafish demonstrated the role of microRNAs in the degradation of maternal mRNAs (Giraldez et al., 2006; Lund et al., 2009). Concomitantly, zygotic genome activation (ZGA) during early development must overcome maternal silencing. Silencing of maternal transcripts is facilitated mainly by three mechanisms, namely chromatinmediated repression, lack of transcription machinery and transcriptional repression due to shortened cell cycles (Schier, 2007).

\section{Small ubiquitin modifier (SUMO)}

Post-translational modifications of proteins play a critical role in many cellular processes by altering functional capability of preexisting proteins, multi-protein complexes, and intracellular structures. In addition to phosphorylation, acetylation and ubiquitination, several small ubiquitinlike proteins (UBLs) have recently been discovered to be reversible post-translational protein modifiers. All UBLs have similar 3D structure, which includes an ubiquitin fold even with highly variable amino acid sequences (Bayer et al., 1998). Among these, small ubiquitin-like 
modifier (SUMO) is the best characterized protein (Hay, 2005). However, unlike ubiquitin that targets proteins for degradation, SUMO-modification affects the coordinate the protein's intracellular localization, interactions, stability and activity (Hay, 2005), thereby affecting a wide range of cellular processes, including gene transcription, cell cycle progression, protein stability, nuclear localization, signal transduction, protein-protein interactions and chromatin dynamics (Geiss-Friedlander and Melchior, 2007).

SUMO constitutes a highly conserved protein family ubiquitously expressed in eukaryotes. SUMO proteins are $\sim 10 \mathrm{kD}$ in size and share only $\sim 18 \%$ sequence identity with ubiquitin, with similar three-dimensional structure as they share ubiquitin fold ( $\beta 1-\beta 2-\alpha 1-\beta 3-\beta 4-\alpha 2-\beta 5)$ (Bayer et al., 1998; Johnson, 2004). S. cerevisiae, C. elegans and D. melanogaster have a single SUMO gene whereas vertebrates have at least three SUMO genes, namely SUMO-1, 2, 3 (Saitoh and Hinchey, 2000), with recent addition of SUMO4, found in humans to date (Geiss-Friedlander and Melchior, 2007). Eight isoforms of SUMO in the Arabidopsis thaliana's genome have been reported (Lois et al., 2003; Kurepa et al., 2003). Mammalian SUMO2 and SUMO3 are $~ 95 \%$ identical with each other and share only 50\% sequence identity to SUMO1. SUMO2/3 are, in part, functionally different from SUMO1 as they conjugate different substrates in vivo, in spite of being activated by the same pathway with the same enzymes. Moreover, on the basis of current studies, SUMO1 responds differently to stress, while SUMO2/3 are almost identical and presumably play identical functions (Saitoh and Hinchey, 2000; Matunis et al., 1996; Hoege et al., 2002). 


\section{SUMOylation}

SUMOylation is a key regulator of numerous biological and cellular events, including gene transcription, cell cycle progression, protein stability, nuclear localization, signal transduction, protein-protein interactions and chromatin dynamics (Geiss-Friedlander and Melchior, 2007). Recently, SUMO and SUMO pathway genes were shown to be important in diverse reproductive functions such as steroid receptor activity, ovulation, gametogenesis and embryogenesis (Broday et al., 2004; Jones, 2006; Abdel-Hafiz et al., 2009; Wang et al., 2010). In C. elegans, the reproductive system is a major SUMO target during postembryonic development, and is required for gonadal and uterine-vulval morphogenesis (Broday et al., 2004).

SUMOylation, the conjugation of SUMO peptide to the target protein, results in the formation of an isopeptide bond between the C-terminal glycine residue of the modifier protein and the $\varepsilon$-amino group of a lysine residue in the acceptor protein by a series of enzymatic reactions similar to those involved in ubiquitination (Johnson, 2004). SUMOylation is a highly conserved process from yeast to humans and targets mostly specific proteins that contain a consensus motif, $\psi \mathrm{KXE}$, where $\psi$ represents a large hydrophobic amino acid (leucine, valine or isoleucine, in general); $\mathrm{K}$ (lysine) is the SUMO attachment site; $\mathrm{X}$ can be any residue and $\mathrm{E}$ is a glutamic acid (Tatham et al., 2001; Johnson, 2004). Modification of target proteins by SUMO is an ATP-dependent enzymatic cascade involving three key enzymes: E1 activating enzyme (the heterodimer SAE1-SAE2), E2 conjugating enzyme (UBC9) and several different E3 ligating enzymes, PIAS, RanBP2/Nup358 and Pc2 (Melchior et al., 2003; Johnson, 2004; Hay, 2005).

Newly synthesized SUMO is immature, as it cannot conjugate to its targets until a SUMOspecific protease generates a mature SUMO by removing some carboxy-terminal residues to expose two C-terminal glycine residues (Hay, 2005). Mature SUMO is further activated by the 
SUMO-specific E1 activating enzyme heterodimer SAE1-SAE2 (also known as AOS1-UBA2) and requires ATP for the formation of a SUMO-adenylate conjugate. The adenylated SUMO is then transferred from SAE2 to the active site cysteine (Cys) of the SUMO-specific E2 conjugating enzyme (UBC9), forming a thioester linkage between the catalytic Cys residue of UBC9 and the C-terminal carboxy group of SUMO. Next, UBC9 transfers SUMO to the target protein (substrate), forming an isopeptide bond between the C-terminal glycine residue of SUMO and a lysine side chain of the target. This step is usually facilitated by SUMO E3 ligases, with exceptions so that some targets are efficiently SUMOylated directly by E2 conjugating enzyme (UBC9). SUMO ligases consist of three different groups of enzymes, viz 1) the protein inhibitor of activated STAT (PIAS) family that contains a C3HC4 RING-like domain (Hochstrasser, 2001; Jackson, 2001; Kotaja, 2002), 2) the nuclear pore protein RanBP2/Nup358 (Pichler et al., 2002), and 3) the polycomb group protein Pc2 (Kagey et al., 2003) (Figure 1).

SUMOylation is a reversible modification, and cleavage of the isopeptide bond between the glycine of SUMO and the lysine of the target is carried out by SUMO-specific proteases of the SENP/Ulp family. Seven SENP genes have been found in humans and they target different SUMO isoforms (Drag and Salvesen, 2008). Three other SUMO proteases have been identified in humans recently, including two desumoylating isopeptidase (DeSI1 and DeI2) and ubiquitinspecific protease-like 1 (USPL1) (Shin et al., 2012). Both the released SUMO and target are then recycled for subsequent rounds of SUMOylation (Melchior, 2000; Johnson, 2004; Hay, 2005; Geiss-Friedlander and Melchior, 2007). 


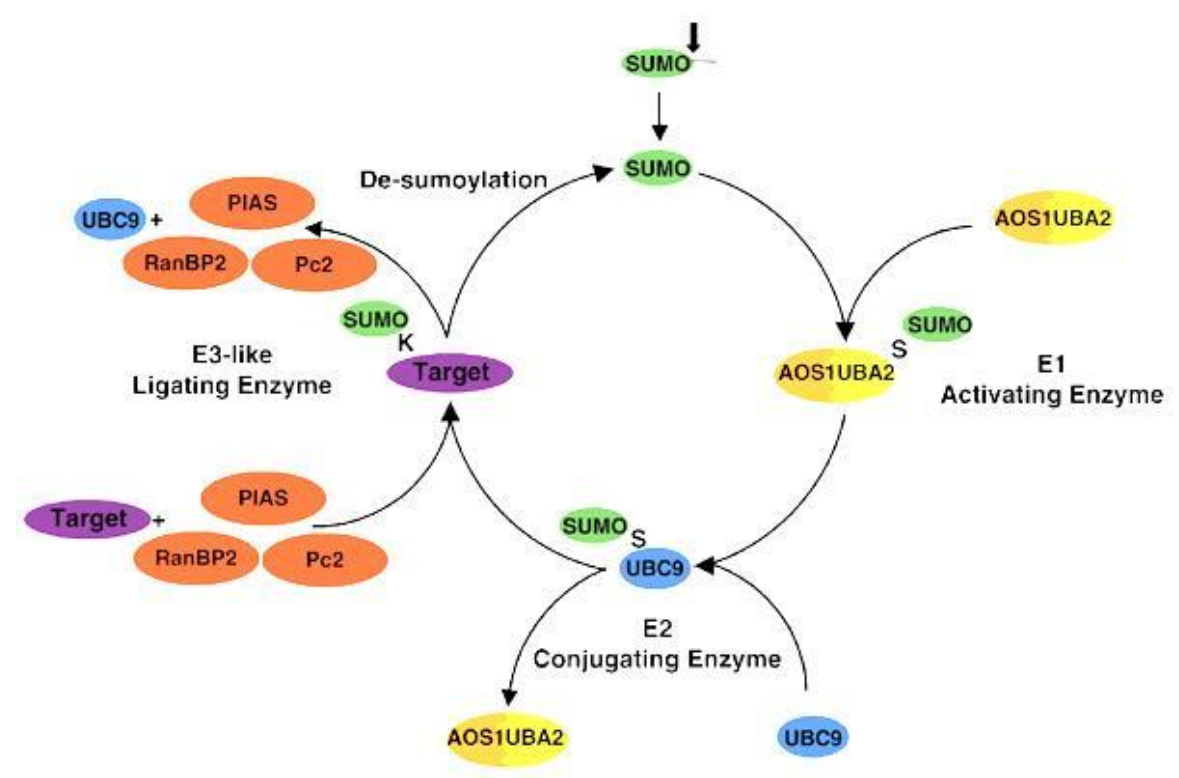

Figure 1. SUMOylation pathway: activation, conjugation and deconjugation (Muller et al., 2004).

\section{SUMO modification in reproductive function}

Some of the germ-cell specific transcription factors such as octamer-binding transcription factor 4 (OCT4) and homeobox protein NANOG (NANOG) are targets of SUMO modification and are regulated by SUMO. OCT4 is a transcription factor that is expressed in embryonic stem (ES) cells and is needed for germ-cell viability (Nichols et al., 1998; Kehler et al., 2004). NANOG, a homeobox transcription factor, plays a critical role in regulating the cell fate of pluripotent ES cells by maintaining pluripotency (Chambers et al., 2003). SUMOylation of OCT4 enhances its stability, transactivating and DNA binding activity (Wei et al., 2007). Moreover, SUMOylation represses NANOG expression and the SUMOylated OCT4 and SOX2 (sex determining region Y-box 2) proteins regulate NANOG in opposing manners (Wu et al., 2012). SUMOylation therefore provides a critical regulatory mechanism to control the stability and activity of some germ-cell specific proteins, such as OCT4 and NANOG, during embryonic development. 
In summary, the preceeding studies show that SUMO and its attendant genes can influence developmental programing of both vertebrate and invertebrate metazoans. Work over the last decade has shown that SUMOylation is an important regulator of protein function and is essential in a number of different biological pathways. However, investigations in regard to how SUMO affects maternal proteins are still limited. Many basic questions regarding SUMO components, mechanism of action and SUMO target proteins remain unanswered and need further investigation. 


\section{Objectives of the Study}

SUMOylation is a key regulator of protein modification and is essential in a number of different biological pathways including embryogenesis. However, studies of SUMO and its related proteins in fish are limited. The main hypothesis of this study is that SUMOylation plays an important role during early embryonic development in rainbow trout and certain oocytespecific factors are SUMOylated. The aims of the study are: 1) identify and characterize genes in the rainbow trout SUMOylation pathway, 2) determine the mRNA expression of Sumo paralogs and related genes in embryogenesis of rainbow trout and; 3) determine if FIGLA and LHX8 are SUMOylated. 


\section{Materials and Methods}

\section{Collection of samples}

Adult rainbow trout were obtained from the National Center for Cool and Cold Water Aquaculture (Kearneysville, WV). Embryonic samples were collected at a series of time points after fertilization, including $0 \mathrm{~h}, 3 \mathrm{~h}, 7.5 \mathrm{~h}, 11.5 \mathrm{~h}, 18 \mathrm{~h}, 27 \mathrm{~h}, 34 \mathrm{~h}, 2 \mathrm{~d}, 3 \mathrm{~d}, 4 \mathrm{~d}, 5 \mathrm{~d}, 6 \mathrm{~d}, 8 \mathrm{~d}, 10 \mathrm{~d}, 12 \mathrm{~d}$, 16d and 25d post fertilization. Tissue samples were collected from mature fish including gill, liver, stomach, head kidney, ovary, muscle, heart, small intestine, spleen, and brain. All samples were quick frozen in liquid nitrogen and stored at $-80^{\circ} \mathrm{C}$ until use.

\section{RNA isolation}

Total RNA from all samples was extracted with Tri-Reagent (Molecular Research Center, Cincinnati, $\mathrm{OH}$ ) according to the manufacturer's protocol. RNA isolated from oocytes and embryos was further purified by lithium chloride precipitation. The RNA integrity was evaluated by gel electrophoresis and the RNA concentration was measured by $\mathrm{OD}_{260}$ reading using a Nanodrop spectrophotometer.

\section{Treatment of RNA samples with DNase}

Six $\mu \mathrm{g}$ of total RNA was treated with DNase by adding $3 \mu 1$ of 10x DNase I buffer and 1 $\mu 1$ of DNase I (Ambion) and the volume of the reaction made up to $30 \mu \mathrm{l}$ with double distilled water $\left(\mathrm{ddH}_{2} \mathrm{O}\right)$. The mixture was incubated at $37^{\circ} \mathrm{C}$ in a waterbath for 30 minutes followed by addition of $5 \mu \mathrm{l}$ of DNase inactivation reagent to inactivate the enzyme. After incubation at room 
temperature for two minutes followed by centrifugation at 14,000g for 2 minutes, the supernatant containing DNase treated RNA was transferred to a fresh tube.

\section{Reverse-transcription polymerase chain reaction (RT-PCR)}

The first strand cDNA synthesis was carried out using DNase treated RNA as template with the reaction mixture containing $8 \mu \mathrm{l}$ of DNase treated RNA, $1 \mu \mathrm{l}$ of Oligo $\mathrm{dT}_{18}$ primer (100 $\mu \mathrm{M}), 1 \mu \mathrm{l}$ of $\mathrm{dNTP} \operatorname{mix}(10 \mu \mathrm{M}), 3 \mu \mathrm{l}$ of random primers $(50 \mathrm{ng} / \mu \mathrm{l}), 4 \mu \mathrm{l}$ of $5 \mathrm{x}$ first strand cDNA synthesis buffer, $2 \mu \mathrm{l}$ of DTT $(0.1 \mathrm{M})$, and $1 \mu \mathrm{l}$ of Super-Transcript III reverse transcriptase $(200 \mathrm{U} / \mathrm{ml}$, Life Technologies). The reverse transcription was performed in a thermal cycler with 5 minutes of priming at $25^{\circ} \mathrm{C}, 30$ minutes of reverse transcription at $42^{\circ} \mathrm{C}$, and 5 minutes of inactivation at $85^{\circ} \mathrm{C}$. The first strand cDNA was diluted by adding $80 \mu 1$ of $\mathrm{dd}_{2} \mathrm{O}$ and was stored at $-80^{\circ} \mathrm{C}$.

The diluted first strand cDNA was used as a template for PCR amplification. PCR amplification was carried out with the reaction mixture composed of $1 \mu 1$ of diluted cDNA, 2.5 $\mu \mathrm{l}$ of gene specific forward primer $(5 \mu \mathrm{M})$ and reverse primer $(5 \mu \mathrm{M})$ (see Table 4 for the list of primer sequences), $1.5 \mu \mathrm{l}$ of $\mathrm{MgCl}_{2}(25 \mathrm{mM}), 0.5 \mu \mathrm{l}$ of dNTP $(10 \mathrm{mM}), 5 \mu \mathrm{l}$ of $5 \mathrm{x}$ PCR buffer,

and $0.25 \mu 1$ of Go Taq ${ }^{\circledR}$ DNA polymerase $(5 \mathrm{u} / \mu 1$, Promega) with the final volume adjusted to 25 $\mu \mathrm{l}$ with $\mathrm{ddH}_{2} \mathrm{O}$. Amplification was carried out in a thermal cycler with 3 minutes of denaturation at $94^{\circ} \mathrm{C}$, followed by $30-35$ cycles of 30 seconds of denaturing at $94^{\circ} \mathrm{C}, 30$ seconds of annealing at $58^{\circ} \mathrm{C}, 1$ minute of extension at $72^{\circ} \mathrm{C}$ with a final extension at $72^{\circ} \mathrm{C}$ for 10 minutes. A negative control was always included and the amplified products were separated through a $1 \%$ agarose gel and stained with 1:10,000 diluted RBG nucleic acid stain (Phenix). 


\section{Quantitative real-time polymerase chain reaction (qPCR) and statistical analysis}

The mRNA expression of genes involved in SUMOylation during embryogenesis were quantified using real-time PCR (qPCR) on a Bio-Rad CFX96 ${ }^{\mathrm{TM}}$ Real-Time PCR Detection System. One $\mu \mathrm{g}$ of DNase treated total RNA was converted into cDNA using miScript reverse transcriptase mix (QIAGEN, Valencia, CA). Gene specific primers for qPCR (Table 4) were designed by Primer 3 software based on the corresponding cDNA sequences. Rainbow trout ribosomal RNA 18S and $\beta$-actin genes were used as endogenous controls (primers shown in Table 4). Each reaction was set up based on $\mathrm{iQ}^{\mathrm{TM}} \mathrm{SYBR}^{\circledR}$ Green Supermix (Bio-Rad, Hercules, CA) manufacturer's protocol in a $20 \mu \mathrm{l}$ reaction containing $100 \mu \mathrm{M}$ of each primer and $3 \mu \mathrm{l}$ of 1:5 diluted cDNA. Cycling parameters were $95^{\circ} \mathrm{C}$ for 3 minutes followed by 40 cycles of $95^{\circ} \mathrm{C}$ for 10 seconds and $60^{\circ} \mathrm{C}$ for 1 minute. Melting curve analyses were programmed after amplification. Standard curves for each gene of interest and the endogenous controls were constructed by using 3 fold serial dilutions of a pooled cDNA sample. The quantity of each sample was determined from respective standard curve and then normalized to the corresponding reference gene. Four biological duplicates for each embryonic stage were performed.

Mean differences in expression of each gene was evaluated as relative fold changes using the lowest expression value as a calibrator. One-way ANOVA was performed on gene expression values by $\mathrm{R}$ software system to determine the significance of differences in gene expression among different samples. Different letters indicate significant differences $(\mathrm{P}<0.05)$.

\section{Analysis of protein sequences}

Alignment of protein sequences were performed using ClustalW2 software (http://www.ebi.ac.uk/Tools/msa/clustalw2/). The evolutionary relationship of SUMO1 and 
UBC9 proteins among different species including human, mouse, rat, cattle, pig, chicken, Xenopus, zebrafish, and rainbow trout was analyzed by Quicktree/Archaeopteryx. Prediction of SUMOylation motifs on the germ-cell specific transcription factors FIGLA and LHX8 was performed using SUMOsp 2.0 software (http://sumosp.biocuckoo.org/program).

\section{Plasmid construction}

The coding sequences for rainbow trout Sumol, Figla, and Lhx8 were amplified by PCR using gene-specific primers containing restriction sites (Table 4). The PCR product for Sumol is flanked by EcoRI and XhoI restriction sites and cloned in frame with a Flag tag, while the PCR product for Figla or Lhx8 is flanked by HindIII and EcoRI cutting sites and cloned in frame with a Myc tag. The amplified coding sequences and pcDNA3.1 vector (Life Technologies) were digested with the same pair of restriction enzymes for $2-3$ hours at $37^{\circ} \mathrm{C}$, and separated through a $1 \%$ agarose gel. The corresponding bands were cut out and extracted by QIAquick gel extraction kit (QIAGEN, Valencia, CA) following the manufacturer's instructions. Insert and vector were incubated with T4 ligase (Promega, $3 \mathrm{u} / \mu \mathrm{l}$ ) at room temperature for 4 hours or at $4^{\circ} \mathrm{C}$ overnight.

E. coli competent cells (Novagen) $\left(>1.5 \times 10^{8} \mathrm{cfu} / \mu \mathrm{g}\right)$ were transformed with $1 \mu \mathrm{l}$ of ligation mixture using a heat shock method involving incubation on ice for 5 minutes, followed by a heat shock for 30 seconds in a $42^{\circ} \mathrm{C}$ water bath, and then on ice for another 2 minutes. The transformation mixture was plated on LB $1 \%$ carbenicillin agar plates. Plates were incubated overnight at $37^{\circ} \mathrm{C}$. A single colony was inoculated the next day and cultured in $3 \mathrm{ml}$ of LB broth with $1 \%$ carbenicillin overnight in shaking incubator at $37^{\circ} \mathrm{C}$ with $250 \mathrm{rpm}$. Plasmids were isolated from the overnight grown culture using a QIAprep miniprep plasmid isolation kit 
(QIAGEN, Valencia, CA) or QIAfilter plasmid midi kit (QIAGEN, Valencia, CA) following manufacturer's instructions.

\section{Cell culture \& transfection}

HEK293 cells were grown in Dulbecco's modified eagles' medium (DMEM) (Life Technologies) supplemented with $10 \%$ fetal bovine serum (Life Technologies) and $1 \%$ penicillin/streptomycin (Life Technologies). HEK293 cells were transiently transfected with $1 \mu \mathrm{g}$ of high quality plasmid using X-tremeGENE 9 DNA transfection reagent (Roche) following the manufacturer's instructions. After 24-48 hours of incubation, cells were collected using Pierce IP (Immunoprecipitation) lysis buffer (Thermo) and centrifuged for 5 minutes at 14,000 rpm. The supernatant was transferred to a fresh tube and stored at $-20^{\circ} \mathrm{C}$ until use.

\section{Western blot analysis}

Thirty $\mu \mathrm{g}$ of total protein from cell lysates was used for Western blot analysis. The samples were boiled at $95^{\circ} \mathrm{C}$ for 5 minutes with 2 x sample buffer $(950 \mu 1$ of Leammli sample buffer and $50 \mu \mathrm{l}$ of $\beta$-mercaptoethanol), followed by centrifugation for 5 minutes at 14,000 rpm. Pre-cast Tris-HCl ready gel (Bio-Rad, Hercules, CA) was loaded with protein samples and Precision Plus Protein ${ }^{\mathrm{TM}}$ Kaleidoscope ${ }^{\mathrm{TM}}$ Standards protein ladder (Bio-Rad, Hercules, CA). Electrophoresis was carried out using 1x running buffer (Tris base/ Glycine/ SDS) for 2 hours at 100 volts, followed by protein transfer from gel to a PVDF membrane in 1x transfer buffer (Tris base/ glycine /SDS /methanol) with an ice pack for 1 hour at 100 volts. Then the PVDF membrane was blocked (5\% non-fat dry milk in 1x PBS) for 2 to 4 hours at room temperature to reduce non-specific binding sites. The membrane was transferred to primary antibody buffer (1: 
1000 dilution in $1 \mathrm{x}$ PBS with $0.1 \%$ Tween-20) and incubated overnight at $4^{\circ} \mathrm{C}$. The primary antibodies used include monoclonal anti-FLAG M2 antibody (F1804, Sigma), monoclonal THE $^{\text {TM }}$ c-myc tag antibody (A00704, GenScript), and polyclonal anti-SUMO-1 (C-terminal) antibody (S5446, Sigma). The membrane was washed with 1x PBS containing 0.1\% Tween-20 (PBST) buffer three times for 5 minutes each, and then incubated in secondary antibody buffer (IRDye $800 \mathrm{CW}$ goat anti-rabbit secondary antibody (LI-COR) and IRDye 680RD goat antimouse secondary antibody (LI-COR), 1:10,000 dilution in 1x PBS containing 0.2\% Tween-20 and $0.01 \%$ SDS in the dark for 30 minutes at room temperature. After washing three times for 5 minutes each in 1x PBST, the membrane was scanned wet or dry using the Odyssey Infrared Imaging System (LI-COR) to detect the protein signal.

\section{Isolation of polyA mRNA}

Total RNA from mature oocytes was prepared using Tri-Reagent (Molecular Research Center, Cincinnati, OH) following the manufacturer's protocol. One mg of total RNA was hybridized with Biotinylated-Oligo(dT) probe and attached with Streptavidin-Paramagnetic Particle (SA-PMPs) using a PolyATract ${ }^{\circledR}$ mRNA isolation system (Promega). The hybrids were captured by magnetic separation stand and washed at high stringency using streptavidin coupled to paramagnetic particles. Supernatant with non poly(A) mRNAs was discarded by multiple washes. Poly(A) mRNA was retained and eluted by adding RNase-free $\mathrm{ddH}_{2} \mathrm{O}$ (Promega).

\section{Construction of cDNA library for yeast two-hybridization}

CDS III Olig-dT Primer was added to mRNA and incubated at $72^{\circ} \mathrm{C}$ for 2 minutes and cooled on ice for 2 minutes before centrifugation at $14,000 \mathrm{~g}$ for 10 seconds. The mixture was 
then added to the reaction mix containing 5X First-Strand Buffer, DTT (100 mM), dNTP mix (10 mM), and SMART MMLV Reverse Transcriptase. After incubation at $42^{\circ} \mathrm{C}$ for 10 minutes, $1 \mu 1$ of SMART III-modified oligo was added and then incubated at $42^{\circ} \mathrm{C}$ for 1 hour. First-strand synthesis was terminated by holding at $75^{\circ} \mathrm{C}$ for 10 minutes. After the sample was cooled to room temperature, $1 \mu$ of RNase H (2 units) was added to the tube followed by incubation at $37^{\circ} \mathrm{C}$ for 20 minutes.

Long distance PCR was performed after first strand cDNA synthesis. Two PCR reactions were set up with each reaction mixture containing $2 \mu \mathrm{l}$ of First-Strand cDNA, $70 \mu 1$ of deionized water, $10 \mu \mathrm{l}$ of 10X Advantage® 2 PCR Buffer, $2 \mu \mathrm{l}$ of 50X dNTP mix, $2 \mu 1$ of 5 ' PCR Primer, 2 $\mu \mathrm{l}$ of 3' PCR Primer, $10 \mu \mathrm{l}$ of 10X Melting Solution, and $2 \mu 1$ of 50X Advantage 2 Polymerase Mix (Clontech). The conditions for PCR amplification were $95^{\circ} \mathrm{C}$ for 30 seconds, 20 cycles of $95^{\circ} \mathrm{C}$ for 10 seconds and $68^{\circ} \mathrm{C}$ for 6 minutes with addition of extension time by 5 seconds with each successive cycle, and $68^{\circ} \mathrm{C}$ for 5 minutes for final extension.

Two PCR products were added to two equilibrated CHROMA SPIN TE-400 columns followed by centrifugation at $700 \mathrm{~g}$ for 5 minutes. The purified samples were combined and transferred to a fresh $1.5 \mathrm{ml}$ tube with $20 \mu \mathrm{l}$ of $3 \mathrm{M}$ sodium acetate and $200 \mu \mathrm{l}$ of ice-cold $100 \%$ ethanol. After chilling at $-20^{\circ} \mathrm{C}$ for 1 hour, the mixture was centrifuged at 14,000 rpm for 20 minutes at room temperature. The pellet was air-dried and resuspended in $20 \mu 1$ of deionized water.

\section{Transformation of cDNA library into pGADT7 vector}

Y187 yeast competent cells were prepared following the manufacturer's protocol (Clontech). Twenty $\mu \mathrm{l}$ of double-strand cDNA and $6 \mu \mathrm{l}$ of pGADT7-Rec plasmid $(0.5 \mu \mathrm{g} / \mu \mathrm{l})$ 
were incubated for 45 minutes at $30^{\circ} \mathrm{C}$ followed by addition of denatured Yeastmaker carrier DNA $(10 \mu \mathrm{g} / \mu \mathrm{l}), \mathrm{Y} 187$ competent cell, and PEG/LiAC buffer (40\% PEG3350, 1 x TE buffer, $0.1 \mathrm{M} \mathrm{LiAC}$ ) followed by addition of $160 \mu \mathrm{l}$ of DMSO. After incubation at $42^{\circ} \mathrm{C}$ for 20 minutes, the cells were centrifuged and the pellet was collected. The pellet was then resuspended in YPD plus medium and incubated at $30^{\circ} \mathrm{C}$ in a shaking incubator for 90 minutes. Cells were centrifuged again and the pellet was resuspended in $9 \mathrm{ml}$ of $0.9 \%(w / v) ~ N a C l$ Solution. A dilution series was performed on SD/-Leucine for the purpose of transformation efficiency. The remaining cells in $\mathrm{NaCl}$ solution were spread on $\mathrm{SD} /$-Leu plates and incubated at $30^{\circ} \mathrm{C}$ for 3-4 days. Two $\mathrm{ml}$ of freezing medium were added to each plate for colony detachment. The cells were aliquoted and stored at $-80^{\circ} \mathrm{C}$ until further use. 


\section{Results}

\section{Identification of cDNA sequences for Sumo related genes in rainbow trout}

Through database mining (GenBank or Gene Index database), ten genes in the rainbow trout SUMOylation pathway were identified, which include Sumo1, Sumo2, Sumo3, Sae1, Sae2 Ubc9, Pias1, Pias4, Cbx4, and Nse2 (Table 2 and Table 3). Only Sumo1, Sumo3 and Ubc9 have complete coding sequences while the others public sequences were only partially. Multiple alignment analysis showed that rainbow trout SUMO1 shares $82 \%$ sequence identity with the human, mouse, rat, cattle, pig, chicken and Xenopus counterparts and 93\% sequence identity with the zebrafish SUMO1 protein (Figure 2). The amino acid sequences of UBC9 are very well conserved among all the species with more than 99\% sequence similarity. Phylogenetic tree analysis of SUMO1 and UBC9 proteins revealed that rainbow trout SUMO1 and UBC9 are closely related to their zebrafish counterparts (Figure 3).

\section{Expression of genes involved in SUMOylation pathway during embryogenesis}

The expression profiles of mRNA of the identified genes during embryonic development of rainbow trout are presented in Figure 4, 5, and 6. Sumo1 is highly expressed in embryos 3d to 5d post fertilization (dpf) (Figure 4A). Sumo2 has lower expression in early stage embryos while higher expression in embryos $3 \mathrm{~d}$ to d8 post fertilization (Figure 4B) was observed. Sumo3 showed high expression in early stage embryos but its expression dramatically reduced in embryos after 27 hours post fertilization (hpf) (Figure 4C). Sael and Sae2 have similar expression patterns where two peaks were observed in $11.5 \mathrm{hpf}$ and $3 \mathrm{dpf}$ stage embryos (Figure 5A, B). Ubc9 showed high expression only in $11.5 \mathrm{hpf}$ and $18 \mathrm{hpf}$ embryos (Figure 5C) while 
Pias 1 and $C b x 4$ are constitutively expressed throughout embryogenesis with two slight peaks at stages 11.5-18 hpf and 3-5 dpf (Figure 6A, C). Increased expression of Pias4 and Nse2 from the day of fertilization to $18 \mathrm{hpf}$ and followed by a gradually decrease thereafter was observed (Figure 6B, 6D).

\section{Tissue distribution profile of Sumo1 and $U b c 9$}

The tissue expression profiles of Sumol and $U b c 9$, two key genes in the SUMOylation pathway, were characterized using 10 different tissues (Figure 7). The expression of Sumo1 and Ubc9 was detected in all tissues studied. More specifically, Sumol showed relatively higher expression in muscle (Figure 7A) compared to other tissues while the expression of $U b c 9$ is numerically higher in brain and ovary (Figure 7B).

\section{Identification of protein interactions between SUMO1 and FIGLA or LHX8}

Analysis of the protein sequences of FIGLA and LHX8 using SUMOsp 2.0 software program predicted putative SUMO attachment sites on both proteins. The specific sites are K107 in FIGLA, and K4 and K188 in LHX8. The coding sequences for Figla, Lhx8, and Sumol were cloned in frame with either a Flag or a Myc tag in an expression vector pcDNA3.1 and cotransfection experiments were performed using HEK293 cells. Western blot analysis indicated that large amounts of plasmids are required for proper expression, as the FIGLA (green band) band faded when less plasmid was used; while the SUMO (red band) band was not observed until a large amount of the Sumo1 plasmid was transfected (Figure 8A). SUMO1 bands were detected by anti-SUMO1 antibodies (Figure 8B), but no additional band was observed at higher 
molecular weight for both FIGLA and LHX8, suggesting that both transcription factors do not interact with SUMO1 under the experimental condition used (Figure 9).

\section{Construction of an oocyte cDNA library in pGADT7-Rec vector for yeast two hybridization}

To better understand the targets of SUMO modification in early embryogenesis, a cDNA library from rainbow trout oocytes was constructed using Y187 yeast for future yeast twohybridization experiments. To determine the quality of the cDNA library, regular PCR was performed to amplify three selected genes (Figla, $L h x 8$ and $U b c 9$ ) using purified library plasmid as a template. As shown in Figure 10, a single band for each gene was observed, indicating that the constructed cDNA library is of good quality and can be used for future studies. 


\section{Discussion}

SUMOylation and deSUMOylation affect multiple biological and cellular events, including gene transcription, cell cycle progression, protein stability, nuclear localization, signal transduction, protein-protein interactions and chromatin dynamics. Recently, SUMO and SUMO pathway genes were shown to be important in diverse reproductive functions such as steroid receptor activity, ovulation, gametogenesis and embryogenesis (Broday et al., 2004; Jones, 2006; Abdel-Hafiz et al., 2009; Wang et al., 2010). In the current study, genes involved in SUMOylation were analyzed for their mRNA expression during early embryogenesis in rainbow trout. Two key genes in the SUMO pathway, Sumo1 and $U b c 9$, were characterized by analyses of their sequences and tissue distributions. In addition, the possibility of two transcription factors, Figla and Lhx8, being SUMOylated were investigated by co-transfection experiments followed by immunoblotting analysis.

From genes identified in the database, three SUMO paralogs, two E1-activating enzymes, a single E2 conjugating enzyme, and four E3 ligases were characterized. Two of the four ligases, PIAS1 and PIAS4 paralogs, belong to the PIAS families; Cbx4 is one of the Pc2 families; NSE2 also belongs to the PIAS family because it contains a C3HC4 RING-like domain. In humans, SUMO-1 is the most studied paralog and its function is different from SUMO2/3 since they conjugate different substrates in vivo. SUMO1 protein sequence is well conserved among human, mouse, western clawed frogs, zebrafish, and rainbow trout. The glycine at the C-terminal end is where the isopeptide bond forms between SUMO and its substrate (Johnson, 2004). The nearby amino acid sequences are quite conserved, suggesting they might help the isopeptide bond formation. Rainbow trout UBC9 is only one amino acid different at the C-terminal end from 
human, mouse, and Xenopus; and one amino acid different near the N-terminal end from zebrafish. Sequence conservation of the UBC9 protein reflects its importance in the SUMOylation pathway. Previous studies have shown that depletion of the single conjugating enzyme, UBC9, resulted in embryonic lethality in zebrafish (Nowak and Hammerschmidt, 2006) and mice (Nacerddine et al., 2005). Therefore, UBC9 may also be an essential enzyme for early embryonic development in rainbow trout since it is the only conjugating enzyme known in the SUMOylation pathway and well conserved among five species.

To better understand the protein relationships of the two most important proteins in the SUMOylation pathway, neighbor-joining phylogenetic trees were constructed for SUMO1 and UBC9 proteins. The amino acid sequences for SUMO1 and UBC9 from 8 different species were used to generate the phylogenetic trees. The phylogenetic tree for SUMO1 shows two main groups: fish and others. The tree for UBC9 indicates that this protein is more conserved among different species even though rainbow trout UBC9 showed its close resemblance with its close relative species zebrafish.

The expression profiles of the Sumo related genes during embryonic development in rainbow trout indicate that gene expression is dynamically regulated. An important period in embryogenesis is the maternal-zygotic transition (MZT) when maternal RNAs are degraded in early embryogenesis beginning from one-cell stage to the blastula and gastrula stages, while zygotic genes are starting to be transcribed (Schier, 2007). MZT happens from 2 to 3 hours post fertilization in zebrafish (Tadros and Lipshitz, 2009). However, the transition in rainbow trout is around 3 to 6 days post fertilization because of the presence of microRNA-430 (unpublished data). The expression of Sumo3, Ubc9, Pias4, and Nse2 increased after fertilization, reaching a peak around $18 \mathrm{hpf}$, followed be a dramatic decrease thereafter. High expression level of Sumol 
and Sumo2 during 3 to $5 \mathrm{dpf}$ could indicate the importance of SUMOylation during the maternalzygotic transition. Characterization of the expression of Sumo related genes in developing embryos provides valuable information about the importance of SUMOylation during embryogenesis in rainbow trout.

Tissue specific expression of SUMO1 indicates its presence in muscle is greater than other tissues as it might be a key regulator in muscle differentiation because recent studies revealed that BS69 protein undergoes SUMO modification and plays an inhibitory role in muscle differentiation (Yu et al., 2009). The brain-specific protein, G-protein coupled receptor interacting scaffold protein (GISP), is SUMOylated to modulate neuronal activity (Kantamneni et al., 2011). Moreover, higher expression level of Ubc9 in ovary and brain suggest their importance in the development of these tissues as absence of UBC9 is embryonic lethal in zebrafish (Nowak and Hammerschmidt, 2006) and mice (Nacerddine et al., 2005).

To better understand the role of SUMO and its related proteins in embryogenesis in fish, the interactions of two germ-cell specific factors, FIGLA or LHX8, with SUMO1 were analyzed. Prediction using Sumo sp2.0 suggests that both proteins have a medium possibility to be recognized by SUMO. However, the present study failed to detect any interactions between FIGLA or LHX8 and SUMO1 under the conditions used. Future experiments may be carried out to confirm these results using in vitro SUMOylation systems. In addition, future experiments may use SUMO2/3 isoforms instead of SUMO1 for co-transfection in order to determine whether FIGLA and LHX8 is SUMOylated.

To further determine the importance of SUMO modification in early embryonic development, a high quality oocyte cDNA library was constructed in yeast for future yeast twohybridization experiments. Because UBC9 is the single conjugating enzyme in the SUMOylation 
pathway, it would be logical to identify SUMO targets using UBC9 as a bait. The rainbow trout UBC9 coding region has been cloned into pGBKT7-BD vector and maintained in Y2HGold yeast strain. Future experiments using UBC9 as a bait and the cDNA library need to be carried out to identify potentially novel SUMO modification substrates.

In conclusion, rainbow trout has all the Sumo related genes. SUMO1 and UBC9 amino acid sequences are well conserved across species where UBC9 is more conserved among the species considered. During embryonic development (egg - d25), expression of all Sumo related genes can be classified into 3 groups (before and after maternal to zygotic transition) based on their expression patterns. Moreover, high expression of Sumol in embryos 3 to 5 days post fertilization suggests its importance during maternal to zygotic transition. Although Figla and Lhx8 might not be the target for SUMO, current and future work will focus on global SUMOylation during embryogenesis and determination of the unknown proteins that interact with UBC9 by yeast two-hybridization. 


\section{Tables and Figures}

Table 2. Genes involved in SUMOylation pathway of rainbow trout identified from current database.

\begin{tabular}{|c|c|c|}
\hline Groups & Genes & Proteins \\
\hline \multirow{3}{*}{ SUMO } & Sumol & Small ubiquitin modifier 1 \\
\hline & Sumo2 & Small ubiquitin modifier 2 \\
\hline & Sumo3 & Small ubiquitin modifier 3 \\
\hline \multirow{2}{*}{$\begin{array}{l}\text { E1 activating } \\
\text { enzyme }\end{array}$} & Sae1 & SUMO activating enzyme subunit 1 \\
\hline & Sae 2 & $\begin{array}{l}\text { SUMO activating enzyme subunit 2, also known as Ubiquitin-like } 1 \\
\text { activating enzyme E1B }\end{array}$ \\
\hline $\begin{array}{l}\text { E2 conjugating } \\
\text { enzyme }\end{array}$ & $U b c 9$ & $\begin{array}{l}\text { SUMO conjugating enzyme UBC } 9 \text {, also known as Ubiquitin- } \\
\text { conjugating enzyme } 9\end{array}$ \\
\hline \multirow{4}{*}{$\begin{array}{l}\text { E3 ligating } \\
\text { enzymes }\end{array}$} & Piasl & $\begin{array}{l}\text { SUMO-protein ligase PIAS1, also known as protein inhibitor of } \\
\text { activated STAT protein } 1\end{array}$ \\
\hline & Pias4 & $\begin{array}{l}\text { SUMO-protein ligase PIAS4, also known as protein inhibitor of } \\
\text { activated STAT protein } 4\end{array}$ \\
\hline & $\mathrm{Cbx} 4$ & $\begin{array}{l}\text { SUMO-protein ligase CBX4, also known as Chromobox protein } \\
\text { homolog } 4\end{array}$ \\
\hline & Nse2 & $\begin{array}{l}\text { SUMO-protein ligase NSE2, also known as Non-structural } \\
\text { maintenance of chromosomes element } 2 \text { homolog }\end{array}$ \\
\hline
\end{tabular}


Table 3. GenBank or Gene Index (TC) number and sequence information for Sumo related genes in rainbow trout.

\begin{tabular}{|c|c|c|c|}
\hline $\begin{array}{l}\text { GenBank or Gene } \\
\text { Index number }\end{array}$ & Gene name & $\begin{array}{c}\text { cDNA } \\
\text { sequence size } \\
\text { (bp) }\end{array}$ & $\begin{array}{c}\text { Protein } \\
\text { size (aa) }\end{array}$ \\
\hline NM_001160594.1 & $\begin{array}{c}\text { SMT3 suppressor of mif two 3 homolog 1 } \\
\text { (Sumo1) }\end{array}$ & 306 & 101 \\
\hline NM_001165057.1 & $\begin{array}{c}\text { SMT3 suppressor of mif two 3 homolog 2 } \\
\text { (Sumo2) }\end{array}$ & 288 & partial \\
\hline BT074221.1 & $\begin{array}{c}\text { Small ubiquitin-related modifier 3 precursor } \\
\text { (Sumo3) }\end{array}$ & 324 & partial \\
\hline TC193515 & SUMO1 activating enzyme subunit 1 (Sae1) & 854 & partial \\
\hline TC203803 & SUMO activating enzyme subunit 2 (Sae2) & 1643 & partial \\
\hline BT073773.1 & SUMO1 conjugating enzyme UBC9 & 477 & 158 \\
\hline TC187252 & Protein inhibitor of activated STAT 1 (Pias1) & 723 & partial \\
\hline CX351371 & protein inhibitor of activated STAT 4 (Pias4) & 249 & partial \\
\hline CA384029.1 & Chromobox homolog 4 (Cbx4) & 600 & partial \\
\hline TC210241 & Non-SMC element 2 (Nse2) & 675 & partial \\
\hline
\end{tabular}


Table 4. Primers used in the study.

\begin{tabular}{|c|c|c|c|}
\hline $\begin{array}{l}\text { PCR } \\
\text { method }\end{array}$ & Primer name & Primer sequences & $\begin{array}{l}\text { Product } \\
\text { size (bp) }\end{array}$ \\
\hline \multirow{24}{*}{$\begin{array}{l}\text { Real-time } \\
\text { PCR }\end{array}$} & SUMO1-F500 & ACTCTATTGGGGCTTCCATGT & \multirow{2}{*}{101} \\
\hline & SUMO1-R600 & AGAAATGACTGTGCGAGGTGT & \\
\hline & SUMO2-F523 & CCTCCGCTAAAACAACTCAGA & \multirow{2}{*}{115} \\
\hline & SUMO2-R637 & AGGTGAACCAACAAGTCACCA & \\
\hline & SUMO3-F1192 & CCACCATGACTTCAACAACCT & \multirow{2}{*}{119} \\
\hline & SUMO3-R1310 & AAGGACTAGTGGACCCATGCT & \\
\hline & SAE1-F615 & AACTGGCTCTGGAAGTGGATT & \multirow{2}{*}{93} \\
\hline & SAE1-R707 & TCAGCAGTACGTGTAGCAGGA & \\
\hline & SAE2-F1381 & ATACGACATGGTAGCCGTCTG & \multirow{2}{*}{103} \\
\hline & SAE2-R1483 & CAAACTCCACAТCCТTCTCCA & \\
\hline & UBC9-F769 & TTACCTCTGGGTTGGAGTGTG & \multirow{2}{*}{124} \\
\hline & UBC9-R892 & AAACCGGTACTGTGCTCTGTC & \\
\hline & PIAS1-F398 & CTACAAGGGGACAACCATCAG & \multirow{2}{*}{105} \\
\hline & PIAS1-R502 & GTAGGGACGGAAGTGGTTGA & \\
\hline & PIAS4-F339 & AAAGCGTAGCTTGTCCTGGAT & \multirow{2}{*}{106} \\
\hline & PIAS4-R444 & TTTAGTGCGGGTCTTCACATC & \\
\hline & CBX4-F126 & GAGAAACCTTCCCTTTGCATC & \multirow{2}{*}{94} \\
\hline & CBX4-R219 & CTTTCGATTCCGCTTCTTCTC & \\
\hline & NSE2-F521 & CTGAGGCAGCAGAGAATATGG & \multirow{2}{*}{103} \\
\hline & NSE2-R623 & TTCACCATCTCCACCTGAGTC & \\
\hline & $\beta$-actin-F541 & GCCGGCCGCGACCTCACAGACTAC & \multirow{2}{*}{72} \\
\hline & $\beta$-actin-R613 & CGGCCGTCCTCCTGAAGCTGTAAC & \\
\hline & R18s-F & GTGGTGTTGAGGAAAGCAGACA & \\
\hline & $\mathrm{R} 18 \mathrm{~s}-\mathrm{R}$ & TGATCACACGTTCCACCTCATC & \\
\hline \multirow{2}{*}{$\begin{array}{l}\text { Regular } \\
\text { PCR }\end{array}$} & SUMO1-ORF-F & $\begin{array}{l}\text { CCGGGAATTCGCCGCCACCATGTCAGACA } \\
\text { CGGAGACAAAAC }\end{array}$ & \multirow{2}{*}{352} \\
\hline & SUMO1-ORF-R & $\begin{array}{l}\text { CCGGCTCGAGCTACTTGTCATCGTCATCCT } \\
\text { TGTAATCATCATTCCAAAGTCCACCGGT }\end{array}$ & \\
\hline
\end{tabular}




\begin{tabular}{|c|c|c|c|}
\hline $\begin{array}{c}\text { PCR } \\
\text { method }\end{array}$ & Primer name & Primer sequences & $\begin{array}{l}\text { Product } \\
\text { size }(b p)\end{array}$ \\
\hline $\begin{array}{c}\text { PCR } \\
\text { method }\end{array}$ & Primer name & Primer sequences & $\begin{array}{l}\text { Product } \\
\text { size (bp) }\end{array}$ \\
\hline \multirow{4}{*}{$\begin{array}{l}\text { Regular } \\
\text { PCR }\end{array}$} & LHX8-ORF-F & $\begin{array}{c}\text { CCGGAAGCTTGCCGCCACCATGTATTGGA } \\
\text { AAAGTGAACTAATG }\end{array}$ & \multirow{2}{*}{1107} \\
\hline & LHX8-ORF-R & $\begin{array}{c}\text { GGCCGAATTCGGCATGGCTGATTGGCAGC } \\
\text { TG }\end{array}$ & \\
\hline & FIGLA-ORF-F & $\begin{array}{c}\text { CCGGAAGCTTGCCGCCACCATGAGTGTCCC } \\
\text { TGAGCGTGAG }\end{array}$ & \multirow{2}{*}{639} \\
\hline & FIGLA-ORF-R & $\begin{array}{c}\text { CCGGGAATTCACTGGGCTGGAACATCATG } \\
\text { GT }\end{array}$ & \\
\hline
\end{tabular}


Homo sapiens Mus_musculus Bos taurus Sus_scrofa RatẼus norvegicus Gallus_gallus Xenopus_tropicalis Danio rerio oncorhyynchus mykiss

Homo sapiens Mus musculus Bos taurus Sus scrofa RatĒus_norvegicus Gallus_gallus Xenopus tropicalis Danio rerio oncorhynchus mykiss

B

Homo_sapiens Mus musculus Xenopus_tropicalis Sus scrófa Gallus_gallus Bos taurus Rattus norvegicus Oncorhȳnchus_mykiss Danio_rerio

Homo_sapiens Mus musculus Xenopus_tropicalis Sus scrōfa Gallus gallus Bos taurus Rattus norvegicus oncorhȳnchus_mykiss Danio_rerio

Homo_sapiens Mus_musculus Xenopus_tropicalis Sus scrōfa Gallus gallus Bos taurus Rattus norvegicus Oncorhȳnchus_mykiss Danio_rerio
MSDOEAKPSTEDLGDKKEG-EYIKLKVIGQDSSEIHFKVKMTTHLKKLKESYCOROGVPM 59 MSDQEAKPSTEDLGDKKEG-EYIKLKVIGQDSSEIHFKVKMTTHLKKLKESYCQRQGVPM 59 MSDQEAKPSTEDLGDKKEG-EYIKLKVIGQDSSEIHFKVKMTTHLKKLKESYCQRQGVPM 59 MSDQEAKPSTEDLGDKKEG-EYIKLKVIGQDSSEIHFKVKMTTHLKKLKESYCQRQGVPM 59 MSDQEAKPSTEDLGDKKEG-EYIKLKVIGQDSSEIHFKVKMTTHLKKLKESYCQRQGVPM 59 MSDQEAKPSAEDLGDKKEG-EYIKLKVIGQDSSEIHFKVKMTTHLKKLKESYCQRQGVPM 59 MSDQEAKPSSEDLGDKKEGGDYIKLKVIGQDSSEIHFKVKMTTHLKKLKESYCQRQGVPM 60 MSDTETKPSS-DGGEKKDG-EYIKLKVIGQDNSEIHFKVKMTTHLKKLKESYSQRQGVPV 58 MSDTETKPSSGDGSEKKDG-EYIKLKVIGQDNSEIHFKVKMTTHLKKLKESYSQRQGVPM 59

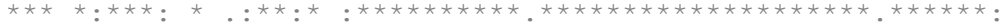

NSLRFLFEGQRIADNHTPKELGMEEEDVIEVYQEQTGGHSTV 101 NSLRFLFEGQRIADNHTPKELGMEEEDVIEVYQEQTGGHSTV 101 NSLRFLFEGQRIADNHTPKELGMEEEDVIEVYQEQTGGHSTV 101 NSLRFLFEGQRIADNHTPKELGMEEEDVIEVYQEQTGGHSTV 101 NSLRFLFEGQRIADNHTPKELGMEEEDVIEVYQEQTGGHSTV 101 NSLRFLFEGQRITDNHTPKELGMEEEDVIEVYQEQTGGHSTV 101 NSLRFLFEGQRISDHQTPKELGMEEEDVIEVYQEQTGGHSTI 102 NSLRFLFEGQRITDNLTPKELGMEDEDVIEVYQEQTGGCRND 100 NTLRFLFEGQRISDNQTPKELGMEDEDVIEVYQEQTGGLWND 101

MSGIALSRLAQERKAWRKDHPFGFVAVPTKNPDGTMNLMNWECAIPGKKGTPWEGGLFKL 60 MSGIALSRLAQERKAWRKDHPFGFVAVPTKNPDGTMNLMNWECAIPGKKGTPWEGGLFKL 60 MSGIALSRLAQERKAWRKDHPFGFVAVPTKNPDGTMNLMNWECAIPGKKGTPWEGGLEKL 60 MSGIALSRLAQERKAWRKDHPFGFVAVPTKNPDGTMNLMNWECAIPGKKGTPWEGGLFKL 60 MSGIALSRLAQERKAWRKDHPFGFVAVPTKNPDGTMNLMNWECAIPGKKGTPWEGGLFKL 60 MSGIALSRLAQERKAWRKDHPFGFVAVPTKNPDGTMNLMNWECAIPGKKGTPWEGGLFKL 60 MSGIALSRLAQERKAWRKDHPFGFVAVPTKNPDGTMNLMNWECAIPGKKGTPWEGGLFKL 60 MSGIALSRLAQERKAWRKDHPFGFVAVPTKNPDGTMNLMNWECAIPGKKGTPWEGGLFKL 60 MSGIALSRLAOERKAWRKDHPFGFVAVPMKNPDGTMNLMNWECAIPGKKGTPWEGGLFKL 60

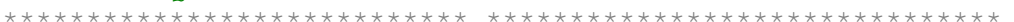

RMLFKDDYPSSPPKCKFEPPLFHPNVYPSGTVCLSILEEDKDWRPAITIKQILLGIQELL 120 RMLFKDDYPSSPPKCKFEPPLFHPNVYPSGTVCLSILEEDKDWRPAITIKQILLGIQELL 120 RMLFKDDYPSSPPKCKEEPPLFHPNVYPSGTVCLSILEEDKDWRPAITIKQILLGIQELL 120 RMLFKDDYPSSPPKCKFEPPLFHPNVYPSGTVCLSILEEDKDWRPAITIKQILLGIQELL 120 RMLFKDDYPSSPPKCKFEPPLFHPNVYPSGTVCLSILEEDKDWRPAITIKQILLGIQELL 120 RMLFKDDYPSSPPKCKEEPPLFHPNVYPSGTVCLSILEEDKDWRPAITIKQILLGIQELL 120 RMLFKDDYPSSPPKCKFEPPLFHPNVYPSGTVCLSILEEDKDWRPAITIKQILLGIQELL 120 RMLFKDDYPSSPPKCKEEPPLFHPNVYPSGTVCLSILEEDKDWRPAITIKQILLGIQELL 120 RMLFKDDYPSSPPKCKFEPPLFHPNVYPSGTVCLSILEEDKDWRPAITIKQILLGIQELL 120

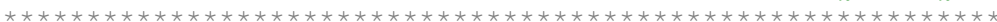

NEPNIQDPAQAEAYTIYCQNRVEYEKRVRAQAKKFAPS 158 NEPNIQDPAQAEAYTIYCQNRVEYEKRVRAQAKKFAPS 158 NEPNIQDPAQAEAYTIYCQNRVEYEKRVRAQAKKFAPS 158 NEPNIQDPAQAEAYTIYCQNRVEYEKRVRAQAKKFAPS 158 NEPNIQDPAQAEAYTIYCQNRVEYEKRVRAQAKKFAPS 158 NEPNIQDPAQAEAYTIYCQNRVEYEKRVRAQAKKFAPS 158 NEPNIQDPAQAEAYTIYCQNRVEYEKRVRAQAKKFAPS 158 NEPNIQDPAQAEAYTIYCQNRVEYEKRVRAQAKKESPS 158 NEPNIQDPAQAEAYTIYCQNRVEYEKRVRAQAKKFSPS 158

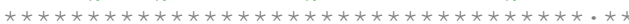

Figure 2. Comparison of rainbow trout SUMO1 and UBC9 amino acid sequences with homologous sequences from other species by ClustalW2 software. A) SUMO1 protein sequences of rainbow trout (NP_001154066.1) shares 82\% sequence homology with human (NP_003343.1), mouse (NP_033486.1), rat (EDL98949.1), cattle (NP_001030535.1), pig (ABK63182.1), chicken (NP_989466.1) and Xenopus (AAH77048.1) SUMO1 proteins, and 93\% sequence identity with zebrafish (NP_998324.1) SUMO1. B) UBC9 protein sequence of rainbow trout (ACO08197.1) shares over 99\% sequence homology with human (NP_003336.1), mouse 
(NP_035795.1), rat (NP_037182.1), cattle (AAI46108.1), pig (NP_001191298.1), chicken (BAB68210.1), Xenopus (NP_001016408.1) and zebrafish (NP_571426.1) UBC9 proteins. 
A

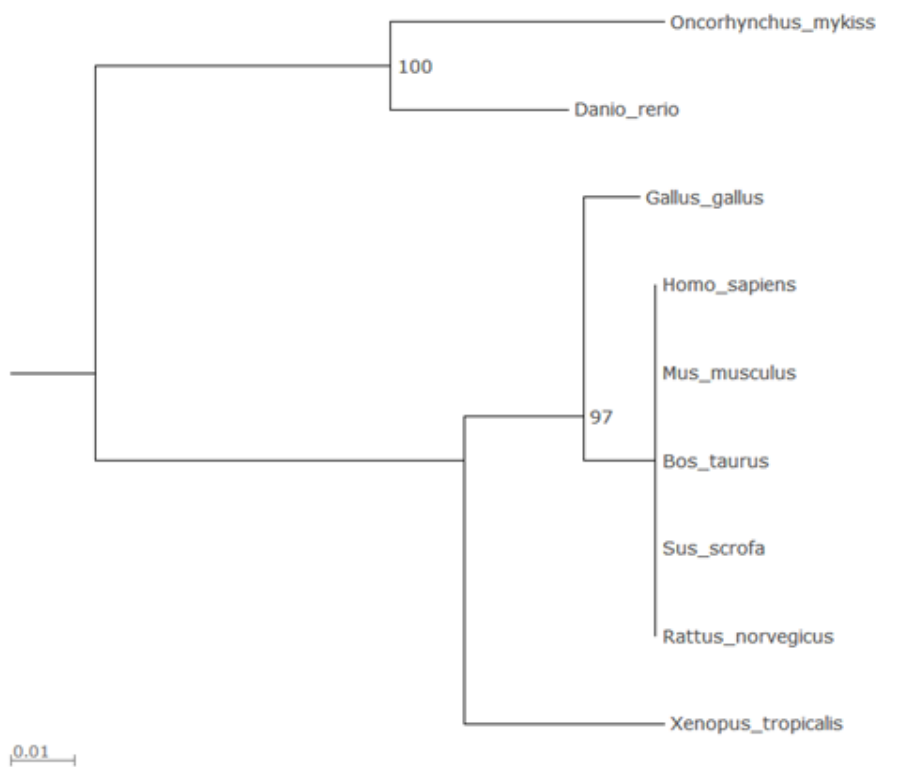

B

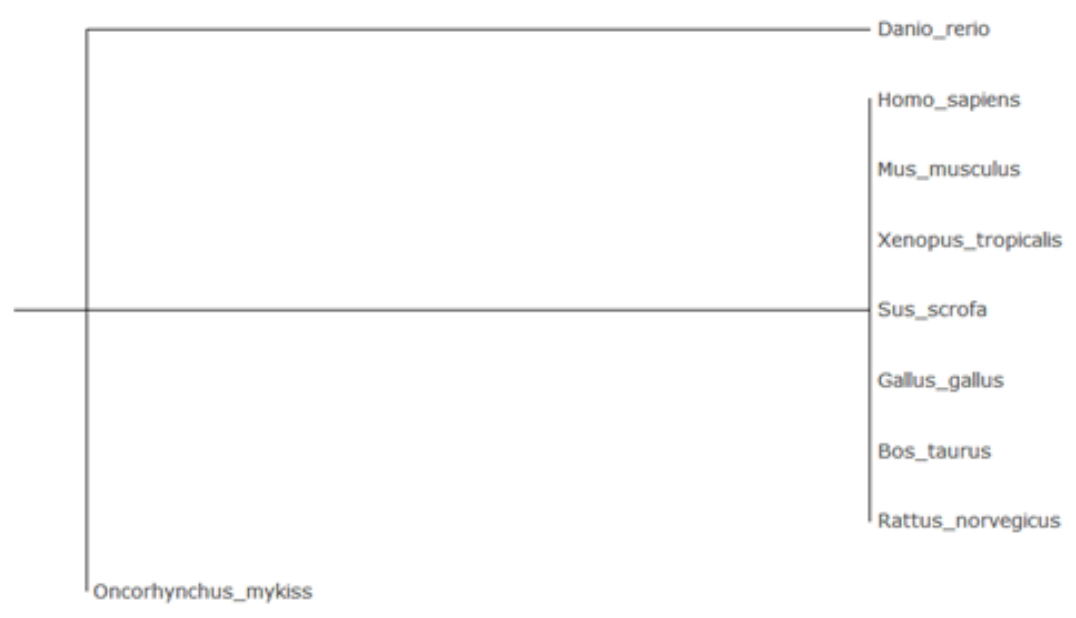

Figure 3. Neighbor joining phylogenetic tree of SUMO1 and UBC9 proteins among different species. A) Phylogenetic tree of SUMO1 among nine species were generated by Quicktree/Archaeopteryx, suggesting rainbow trout has higher sequence homology with zebrafish. B) Phylogenetic tree of UBC9 indicates rainbow trout and zebrafish have a closer connection. Accession numbers for protein sequences listed: SUMO1, human (NP_003343.1), mouse (NP_033486.1), rat (EDL98949.1), cattle (NP_001030535.1), pig (ABK63182.1), chicken 
(NP_989466.1), Xenopus (AAH77048.1), zebrafish (NP_998324.1), rainbow trout (NP_001154066.1); UBC9, human (NP_003336.1), mouse (NP_035795.1), rat (NP_037182.1), cattle (AAI46108.1), pig (NP_001191298.1), chicken (BAB68210.1), Хenopus (NP_001016408.1) and zebrafish (NP_571426.1), rainbow trout (ACO08197.1). 
A

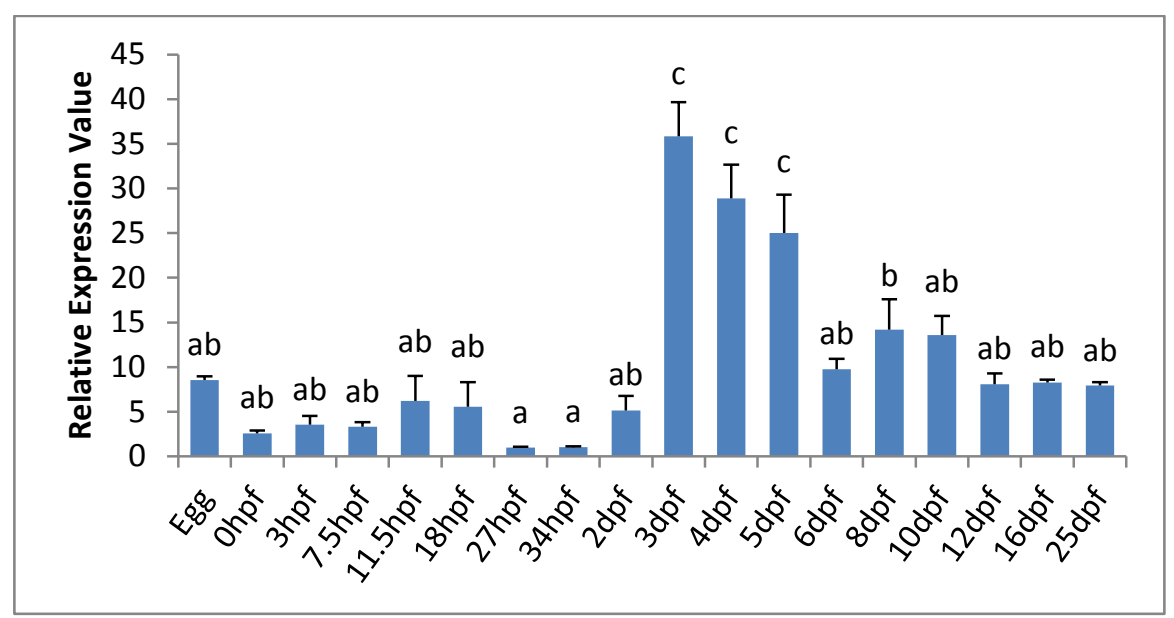

B

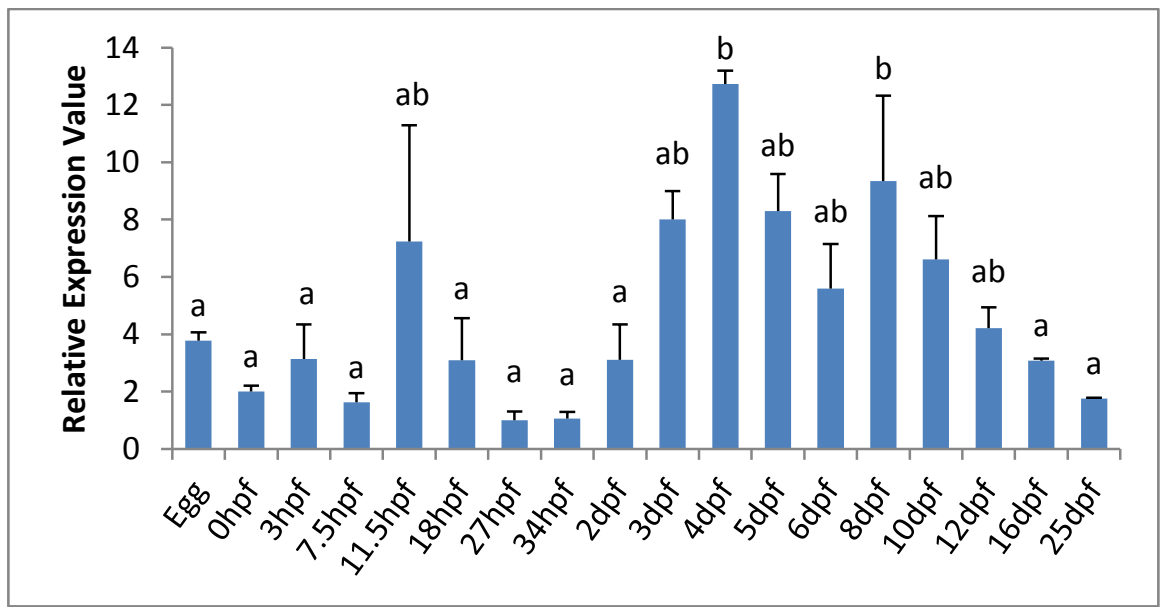

$\mathrm{C}$

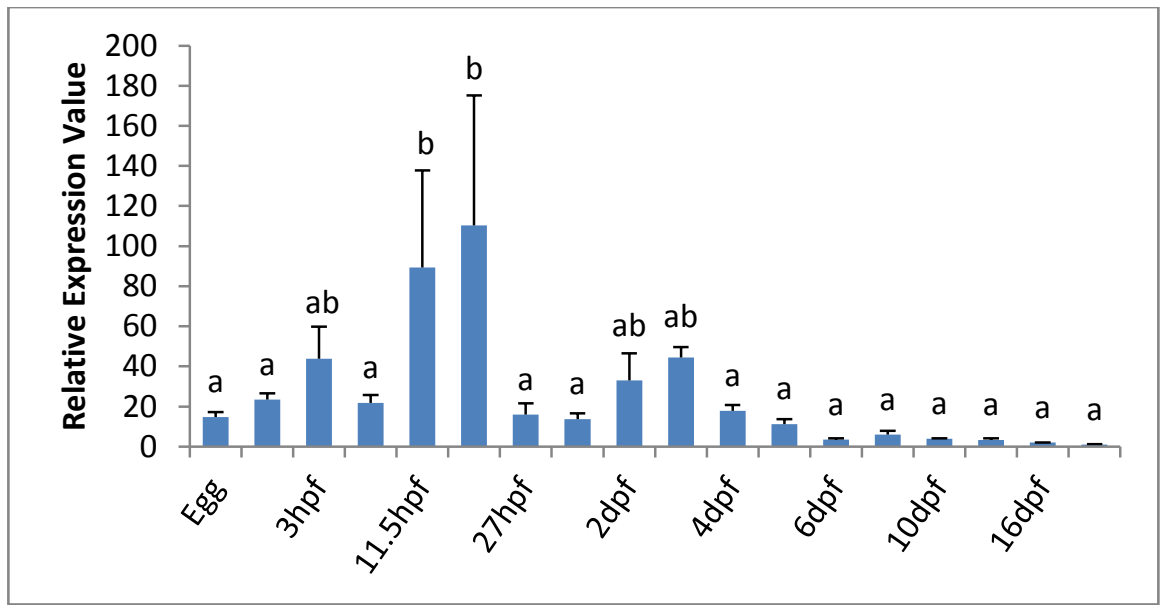

Figure 4. mRNA expression of SUMO paralogs during embryogenesis. A) Sumo1, B) Sumo2, and C) Sumo3. mRNA expression profile was analyzed by quantitative real-time PCR. Data were normalized relative to abundance of the endogenous control ribosomal RNA $18 \mathrm{~S}$ and are expressed as relative fold changes $(n=4$, mean \pm SEM). Different letters indicate statistical difference $(\mathrm{p}<0.05)$. 
A

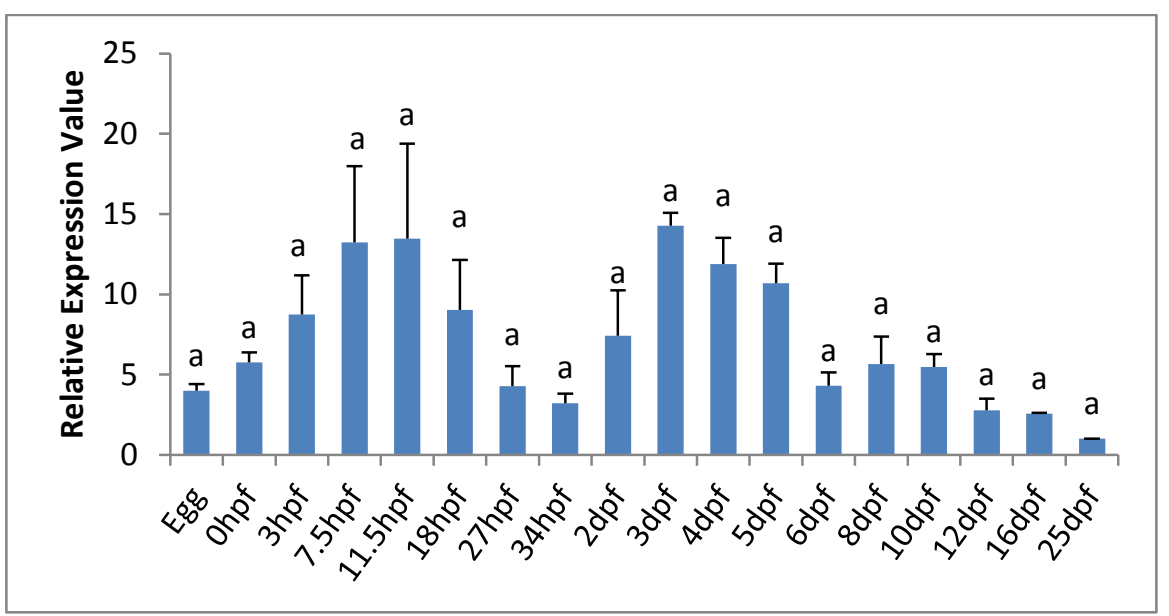

B

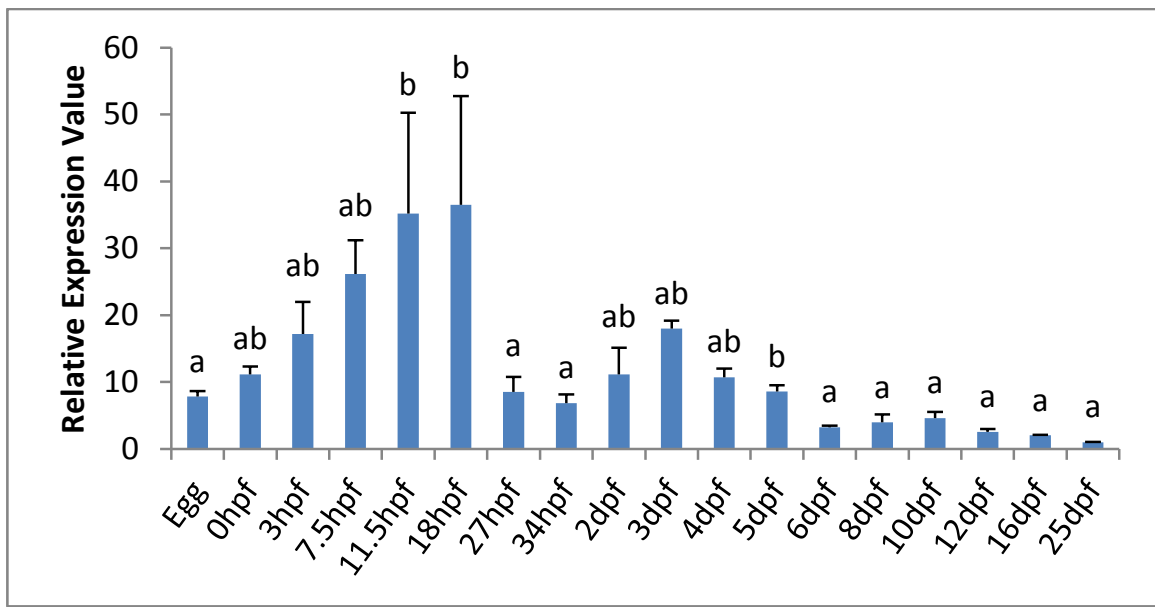

C

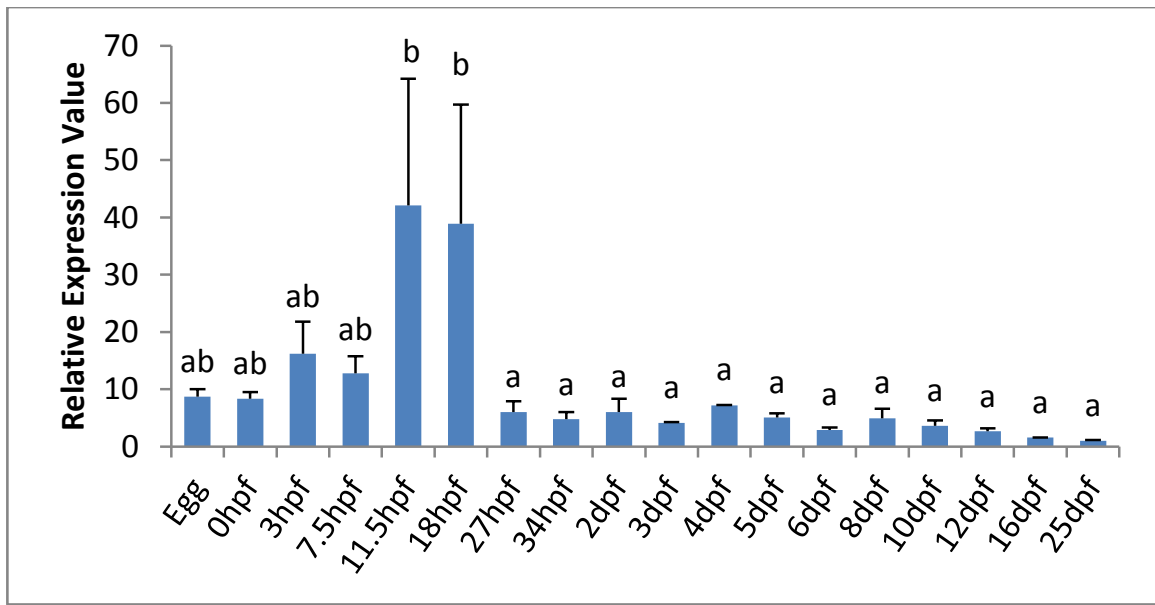

Figure 5. mRNA expression of SUMO activating and conjugating enzymes during embryogenesis. A) Sae1, B) $S a e 2$ and C) $U b c 9$. mRNA expression profile was analyzed by quantitative real-time PCR. Data were normalized relative to abundance of the endogenous control ribosomal RNA $18 \mathrm{~S}$ and are expressed as relative fold changes $(n=4$, mean \pm SEM). Different letters indicate statistical difference $(\mathrm{p}<0.05)$. 
A

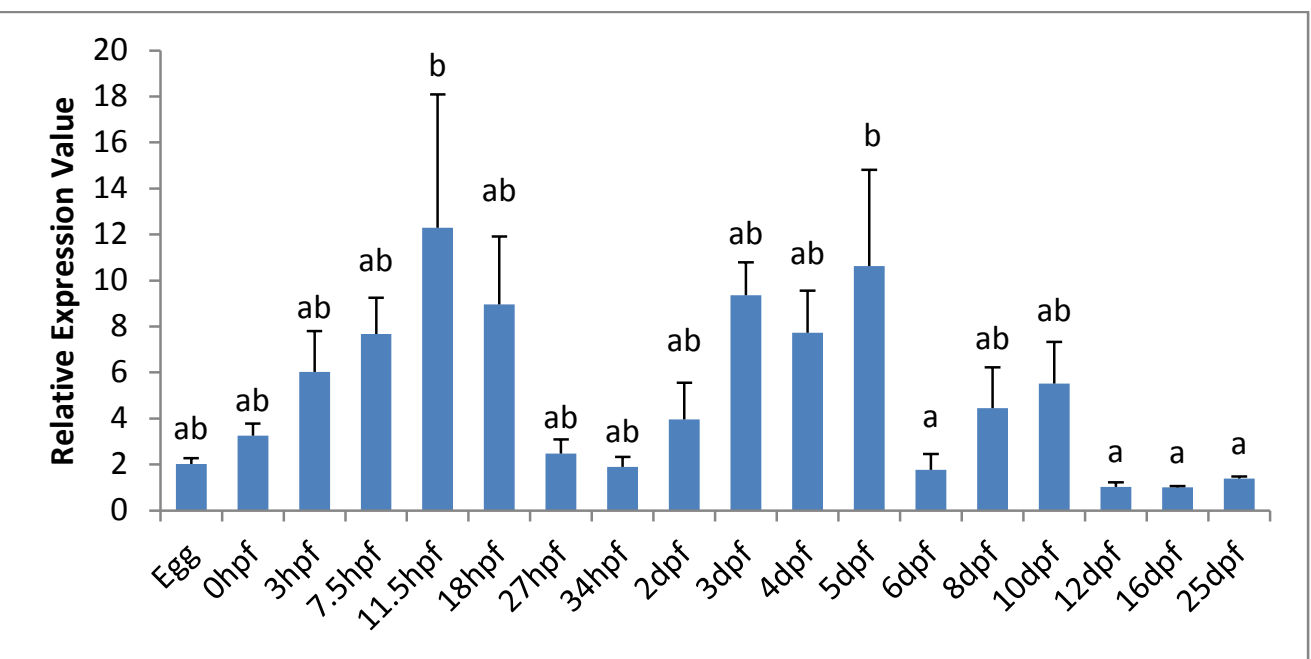

B

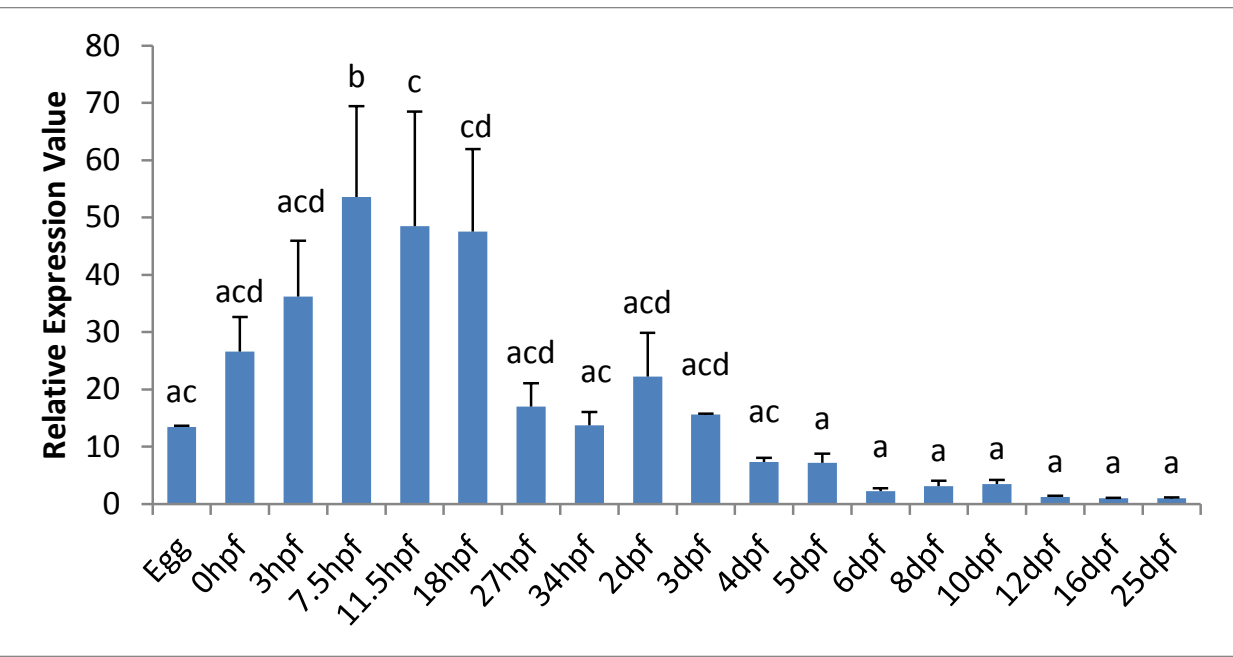

C

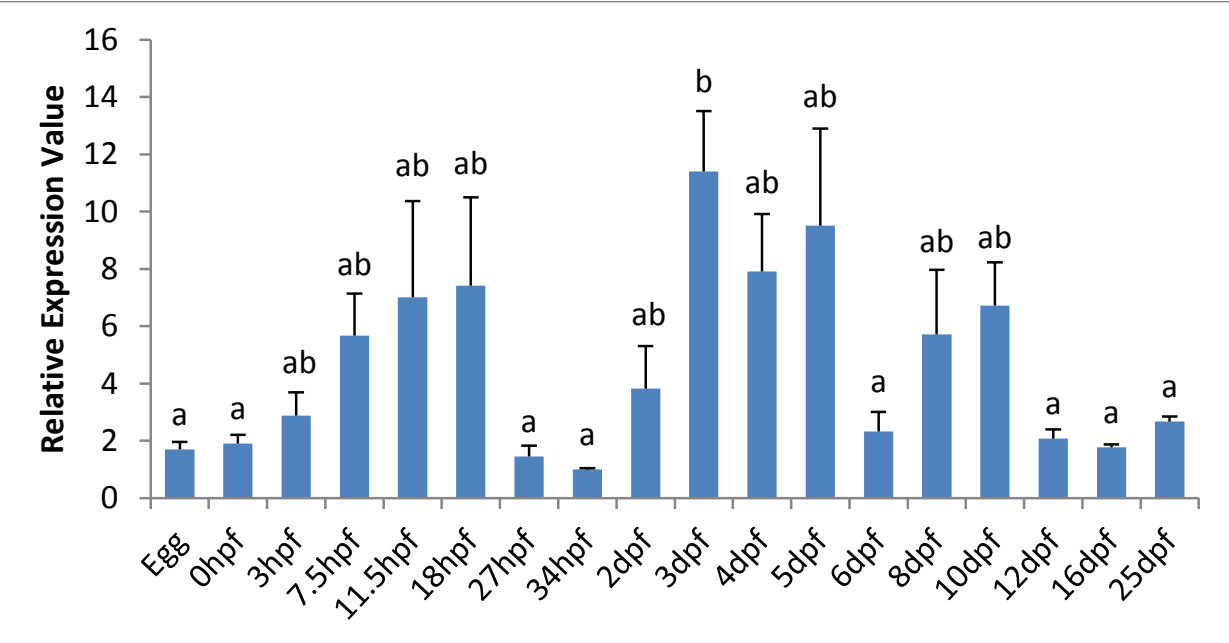


$\mathrm{D}$

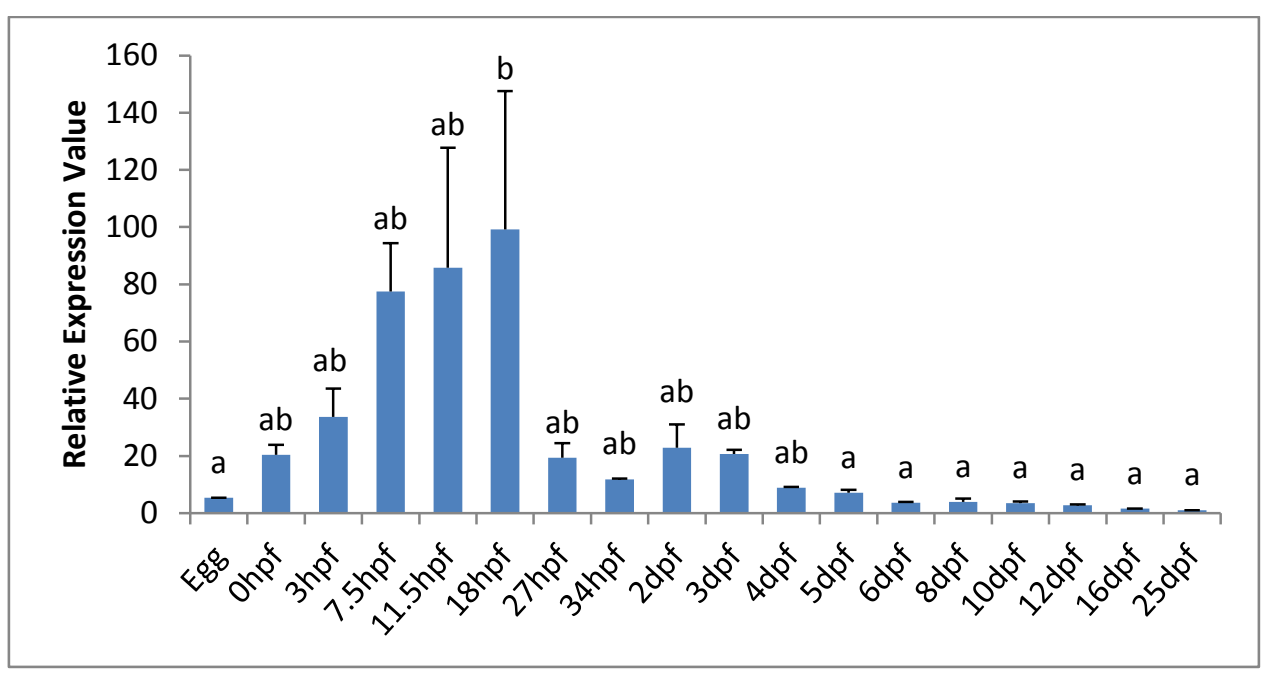

Figure 6. mRNA expression of SUMO ligases during embryogenesis. A) Pias1, B) Pias4, C) Cbx4 and D) Nse2. mRNA expression profile was analyzed by quantitative real-time PCR. Data were normalized relative to abundance of the endogenous control ribosomal RNA 18S and are expressed as relative fold changes $(n=4$, mean $\pm S E M)$. Different letters indicate statistical difference $(\mathrm{p}<0.05)$. 
A

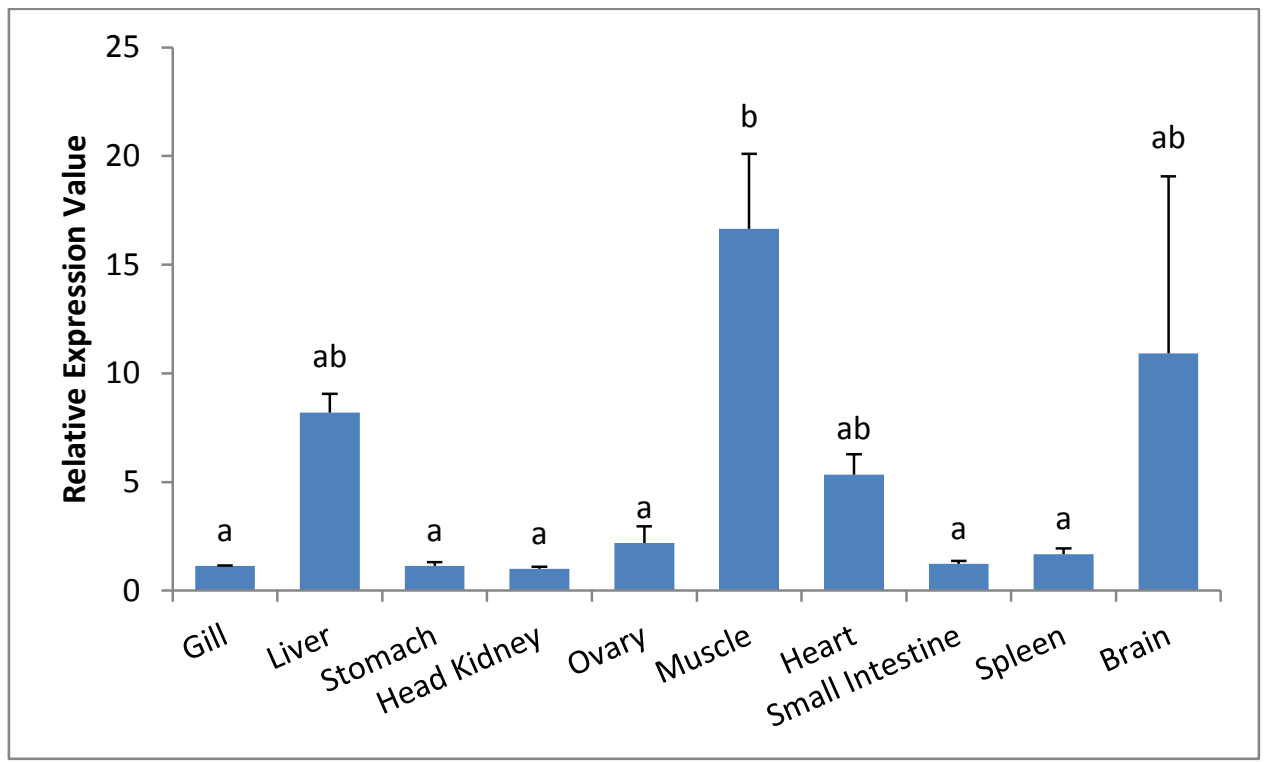

B

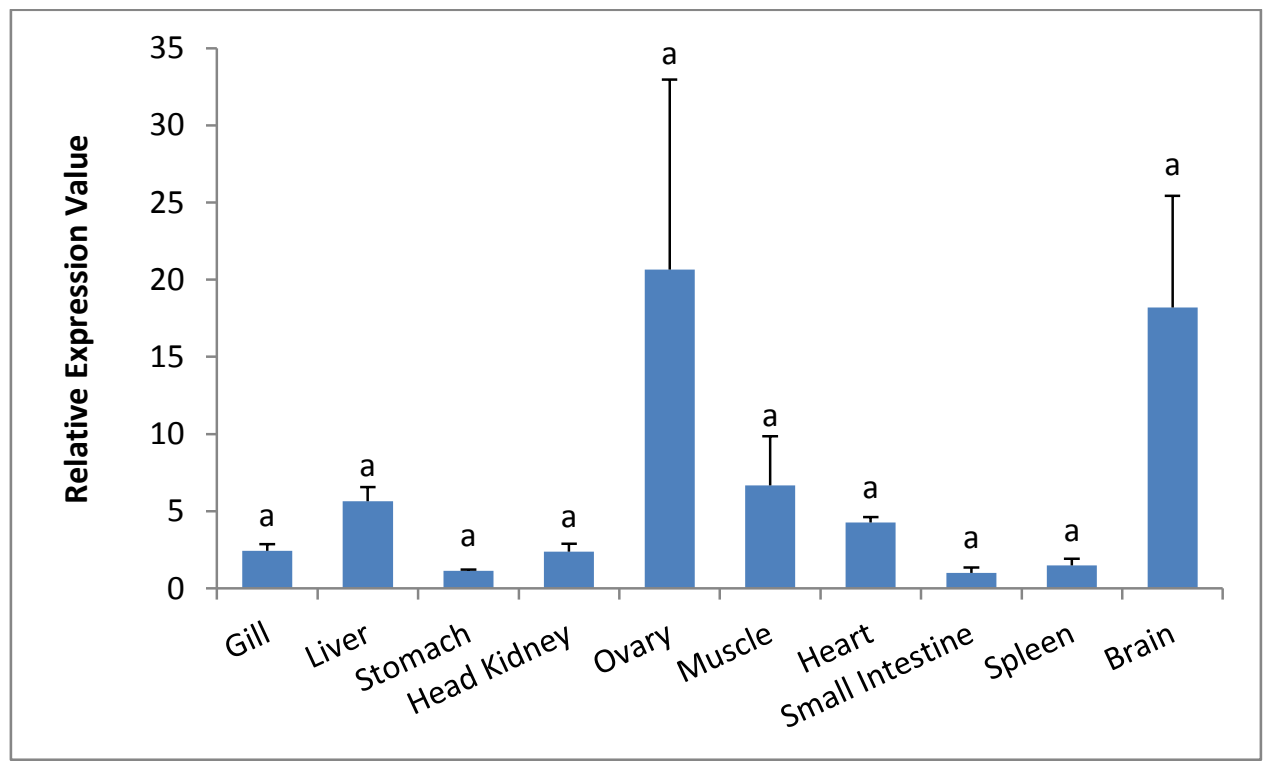

Figure 7. Tissue distribution of $S u m o 1$ and $U b c 9$ mRNA analyzed by quantitative real-time PCR. Abundance of A) Sumo1 and B) Ubc9 mRNA in each sample was normalized relative to abundance of the endogenous control $\beta$-actin gene. Data are expressed as relative fold changes $(\mathrm{n}=4$, mean $\pm \mathrm{SEM})$. Different letters indicate statistical difference $(\mathrm{p}<0.05)$. 
A

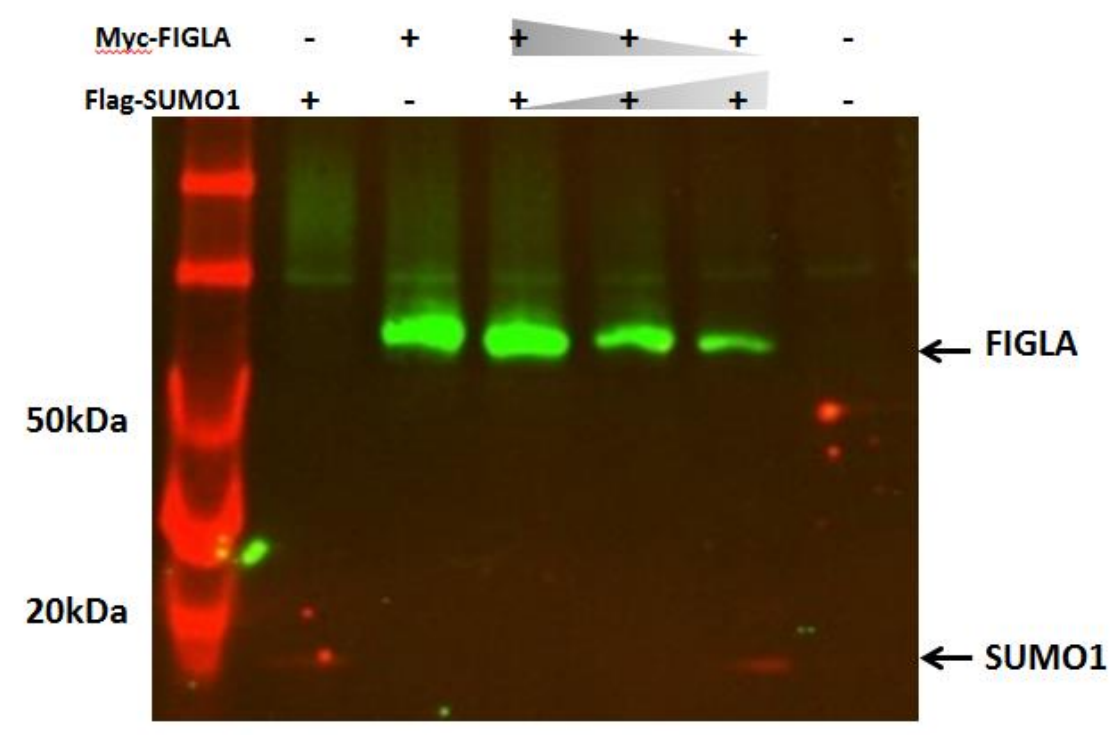

B

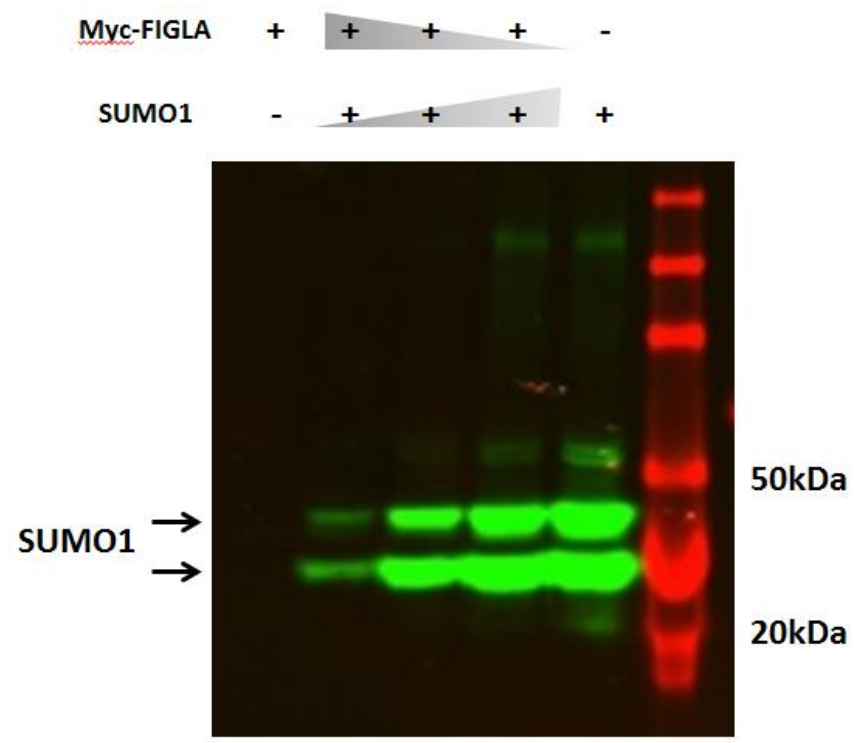

Figure 8. Analysis of protein interaction between FIGLA and SUMO1 in HEK293 cells. A) Western blot analysis showing Myc-FIGLA and Flag-SUMO1 protein bands detected by antiMyc and anti-Flag antibodies. B) Western blot analysis showing SUMO1 protein bands detected by anti-SUMO1 antibodies. Myc-FIGLA and Flag-SUMO1 expression plasmids were coexpressed in HEK293 cell, with increasing amount of Flag-SUMO1 plasmid and decreasing amount of Myc-FIGLA plasmid. No additional band at higher molecular weight representing SUMOylated FIGLA protein was detected. The experiment was repeated three times with similar results. 
A

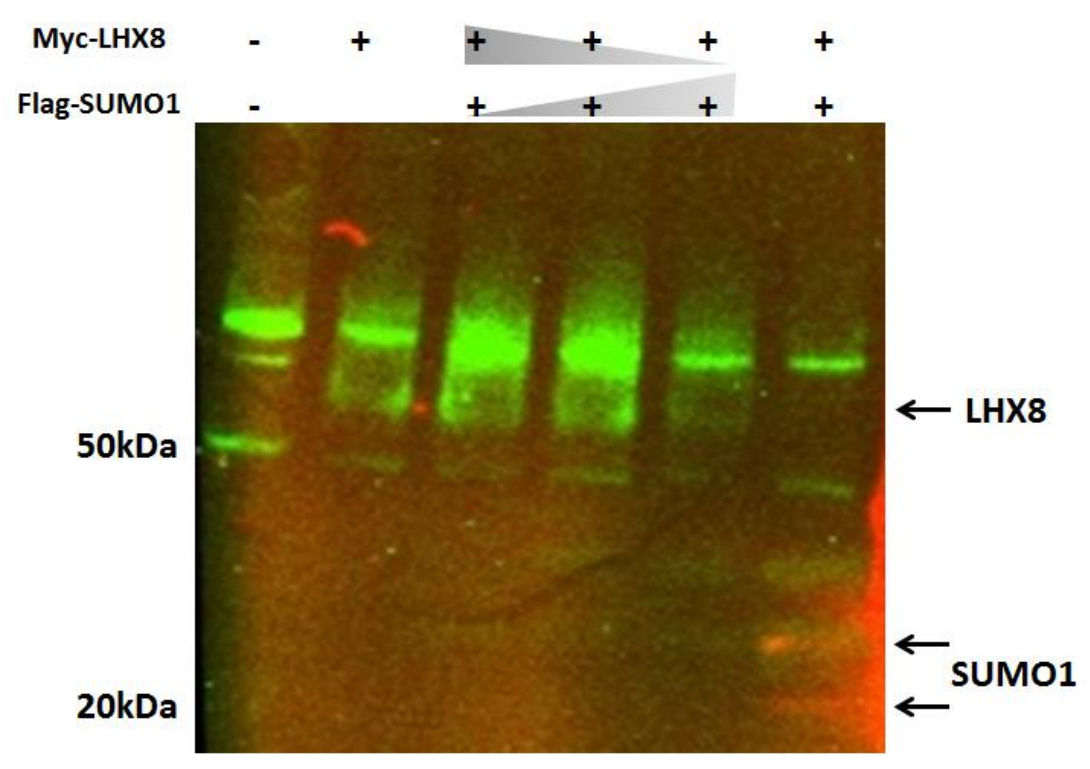

B

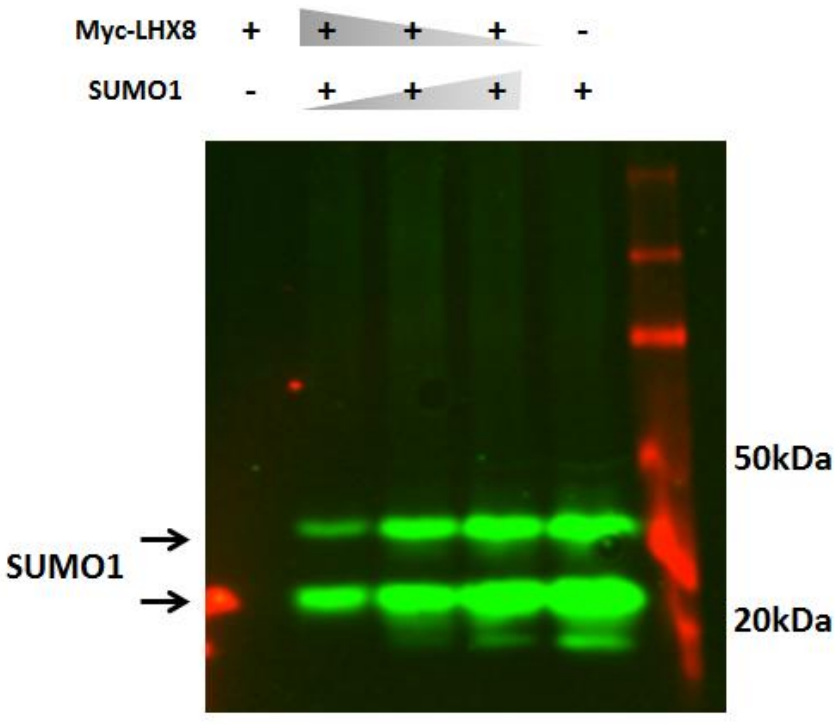

Figure 9. Analysis of protein interaction between LHX8 and SUMO1 in HEK293 cells. A) Western blot analysis showing Myc-LHX8 and Flag-SUMO1 protein bands detected by antiMyc and anti-Flag antibodies. B) Western blot analysis showing SUMO1 protein bands detected by anti-SUMO1 antibodies. Myc-LHX8 and Flag-SUMO1 expression plasmids were coexpressed in HEK293 cell, with increasing amount of Flag-SUMO1 plasmid and decreasing amount of Myc-LHX8 plasmid. No additional band at higher molecular weight representing SUMOylated LHX8 protein was detected. The experiment was repeated three times with similar results. 


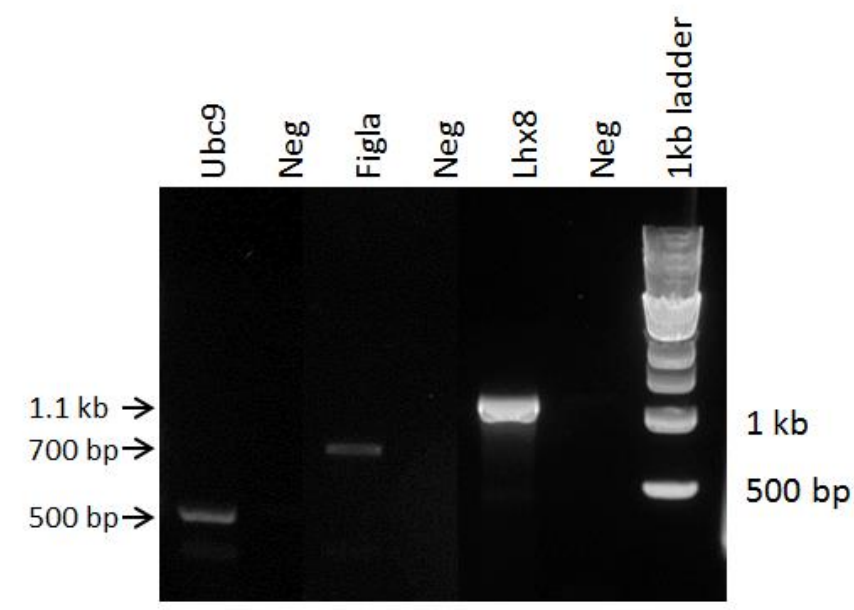

Figure 10. Evaluation of the oocyte cDNA library quality by PCR amplification of Ubc9, Figla, and $\boldsymbol{L h} \boldsymbol{h} \boldsymbol{8}$ genes. PCR amplification of $U b c 9$, Figla and Lhx8 genes using purified library plasmid from Y187 yeast as a template showed single bands for each gene, indicating the cDNA library is of good quality. Each gene was amplified by gene specific primers with negative controls for each gene (Neg). 


\section{References}

Abdel-Hafiz H, Dudevoir ML, Horwitz KB. 2009. Mechanisms underlying the control of progesterone receptor transcriptional activity by SUMOylation. J Biol Chem 284:9099-9108.

Bayer P, Arndt A, Metzger S, Mahajan R, Melchior F, Jaenicke R, Becker J. (1998). Structure determination of the small ubiquitin-related modifier SUMO-1. J Mol Biol 280(2): 275-286.

Brevini T, Cillo F, Colleoni S, Lazzari G, Galli C, Gandolfi F. 2004. Expression pattern of the maternal factor zygote arrest 1 (Zar1) in bovine tissues, oocytes, and embryos. Mol Reprod Dev 69:375-380.

Broday L, Kolotuev I, Didier C, Bhoumik A, Gupta B, Sternberg P, Podbilewicz B, Ronai Z. 2004. The small ubiquitin-like modifier (SUMO) is required for gonadal and uterinevulval morphogenesis Caenorhabditis elegans. Gene Dev 18:2380-2391.

Brooks S, Tyler CR, Sumpter JP. 1997. Egg quality in fish: what makes a good egg? Rev Fish Biol Fish 7:387-416.

Burns KH, Viveiros MM, Ren Y, Wang P, DeMayo FJ, Frail DE, Eppig JJ, Matzuk MM. 2003. Roles of NPM2 in chromatin and nucleolar organization in oocytes and embryos. Science 300(5619):633-636

Chambers I, Colby D, Robertson M, Nichols J, Lee S, Tweedie S, Smith A. (2003) Functional expression cloning of Nanog, a pluripotency sustaining factor in embryonic stem cells. Cell 113: 643-655.

Choi Y, Ballow DJ, Xin Y, Rajkovic A. 2008. Lim homeobox gene, lhx8, is essential for mouse oocyte differentiation and survival Biol. Reprod 79: $442-449$.

Dawid IB. 1998. LIM protein interactions: drosophila enters the stage. Trends Genet 14(12):480-482.

Dong J, Albertini DF, Nishimori K, Kumar TR, Lu N, Matzuk MM. 1996. Growth differentiation factor-9 is required during early ovarian folliculogenesis. Nature 383(6600):531535.

Drag M and Salvesen GS. 2008 DeSUMOylating enzymes-SENPs. IUBMB life 60(11): 734-742 
Galloway SM, McNatty KP, Cambridge LM, Laitinen MP, Juengel JL, Jokiranta TS, McLaren RJ, Luiro K, Dodds KG, Montgomery GW, Beattie AE, Davis GH, Ritvos O. 2000. Mutations in an oocyte-derived growth factor gene (BMP15) cause increased ovulation rate and infertility in a dosage-sensitive manner. Nature genet 25(3):279-283.

Geiss-Friedlander R and Melchior F. 2007. Concepts in sumoylation: a decade on. Nat Rev Mol Cell Biol 8:947-956.

Giraldez AJ, Mishima Y, Rihel J, Grocock RJ, Van Dongen S, Inoue K, Enright AJ, Schier AF. 2006. Zebrafish miR-430 promotes deadenylation and clearance of maternal mRNAs. Science 312(5770): 75-9.

Girbert SF. 2003. Developmental Biology. Sinauer Associates, Inc.,Sunderland.

Grigoriou M, Tucker AS, Sharpe PT, Pachnis V. 1998. Expression and regulation of Lhx6 and Lhx7, a novel subfamily of LIM homeodomain encoding genes, suggests a role in mammalian head development. Development 125:2063-2074.

Hay RT. 2005. SUMO: a history of modification. Mol Cell 18:1-12.

Hochstrasser M. 2001. SP-RING for SUMO: new functions bloom for a ubiquitin-like protein. Cell 107:5-8

Hoege C, Pfander B, Moldovan GL, Pyrowolakis G, Jentsch S. 2002. RAD6-dependent DNA repair is linked to modification of PCNA by ubiquitin and SUMO. Nature 419(6903):135-41

Hu W, Gauthier L, Baibakov B, Jimenez-Movilla M, Dean J. 2010. FIGLA, a basic helixloophelix transcription factor, balances sexually dimorphic gene expression in postnatal oocytes. Mol Cell Biol 30:3661-3671.

Hunter CS and Rhodes SJ. 2005. LIM-homeodomain genes in mammalian development and human disease. Mol Biol Rep 32(2): 67-77.

Johnson ES. 2004. Protein modification by SUMO. Annu Rev Biochem 73:355-382.

Jones MC, Fusi L, Higham JH, Abdel-Hafiz H, Horwitz KB, Lam EW, Brosens JJ. 2006. Regulation of the SUMO pathway sensitizes differentiating human endometrial stromal cells to progesterone. PNAS 103:16272-16277.

Kagey MH, Melhuish TA, Wotton D. 2003. The polycomb protein Pc2 is a SUMO E3.Cell 113:127-37. 
Kantamneni S, Wilkinson KA, Jaafari N, Ashikaga E, Rocca D, Rubin P, Jacobs SC, Nishimune A, Henley J. 2011. Activity-dependent SUMOylation of the brain-specific scaffolding protein GISP. BBRC 409(4): 657-662.

Kehler J, Tolkunova E, Koschorz B, Pesce M, Gentile L, Boiani M, Lomeli H, Nagy A, McLaughlin KJ, Scholer HR, Tomilin A. 2004. Oct4 is required for primordial germ cell survival. EMBO Rep 5(11): 1078-83.

Kennedy AE and Dickinson AJG. 2012. Median facial clefts in Xenopus laevis: Roles of retinoic acid signaling and homeobox genes. Dev Biol 365(1): 229-240.

Kimmel CB, Ballard WW, Kimmel SR, Ullmann B and Schilling TF. 1995. Stages of embryonic development of the zebrafish. Dev Dyn 203: 253-310.

Kitanaka J, Takemura M, Matsumoto K, Mori T, Wanaka A. 1998. Structure and chromosomal localization of a murine LIM/homeobox gene, Lhx8. Genomics 49: 307 - 309.

Kjorsvik E, Mangor-Jensen A, Homefjord I. 1990. Egg quality in fishes. Adv Mar Biol 26:71113.

Kotaja N, Karvonen U, Janne OA, and Palvimo JJ. 2002. PIAS proteins modulate transcription factors by functioning as SUMO-1 ligases. Mol. Cell. Biol 22:5222-5234.

Kurepa J, Walker JM, Smalle J, Gosink MM, Davis SJ, Durham TL, Sung DY, Vierstra RD. The small ubiquitin-like modifier (SUMO) protein modification system in Arabidopsis. Accumulation of SUMO1 and -2 conjugates is increased by stress. JBC 278(9): 6862-72.

Jackson PK. 2001. A new RING for SUMO: wrestling transcriptional responses into nuclear bodies with PIAS family E3 SUMO ligases. Genes Dev 15: 3053-58.

Jagarlamudi K and Rajkovic A. 2012. Oogenesis: transcriptional regulators and mouse models. Mol cell endocrinol 356(1-2): 31.

Lee CS. 2003. Biotechnological advances in finfish hatchery production: a review. Aquaculture 227(1-4):439-458.

Liang L, Soyal SM, Dean J. 1997. FIGalpha, a germ cell specific transcription factor involved in the coordinate expression of the zona pellucida genes. Development 124:4939-4947.

Lois LM, Lima CD, Chua NH. 2003. Small ubiquitin-like modifier modulates abscisic acid signaling in arbidopsis. Plant cell 15(6): 1347-59 
Lund E, Liu M, Hartley RS, Sheets MD, Dahlberg JE. 2009. Deadenylation of maternal mRNAs mediated by miR-427 in Xenopus laevis embryos. RNA 12: 2351-63

Matsumoto K, Tanaka T, Furuyama T, Kashihara Y, Mori T, Ishii N, Kitanaka J, Takemura M, Tohyama M, Wanaka A. Neurosci Lett. 1996. L3, a novel murine LIM-homeodomain transcription factor expressed in the ventral telencephalon and the mesenchyme surrounding the oral cavity. Neurosci Lett 204:113-116.

Matunis MJ, Coutavas E, Blobel G. 1996. A novel ubiquitin-like modification modulates the partitioning of the Ran-GTPase-activating protein RanGAP1 between the cytosol and the nuclear pore complex. J. Cell Biol 135(6):1457-70.

Melchior F. 2000. SUMO--nonclassical ubiquitin. Annual review of cell and developmental biology 16:591.Melchior F, Schergaut M, Pichler A. 2003. SUMO: ligases, isopeptidase and nuclear pores. Trends Biochem Sci 28:612-618.

Michailidis G, Argiriou A, Avdi M. 2010. Expression of chicken zygote arrest 1 (Zar1) and Zar1-like genes during sexual maturation and embryogenesis. Vet Res Commun 34:173-184.

Muller S, Ledl A, Schmidt D. 2004. SUMO: a regulator of gene expression and genome integrity. Oncogene 23(11): 1998-2008.

Nacerddine K, Lehembre F, Bhaumik M Artus J, Cohen-Tannoudji M, Babinet C, Pandolfi PP, Dejean A. 2005. The SUMO pathway is essential for nuclear integrity and chromosome segregation in mice. Dev Cell 9:769-779.

Newport J and Kirschner M. 1982. A major developmental transition in early Xenopus embryos: I. characterization and timing of cellular changes at the midblastula stage. Cell 30(3): 675-86.

Newport J and Kirschner M. 1982. A major developmental transition in early Xenopus embryos: II. control of the onset of transcription. Cell 30 (3): 687-96.

Nichols J, Zevnik B, Anastassiadis K, Niwa H, Klewe-Nebenius D, Chambers I, Scholer H, Smith A. 1998. Formation of pluripotent stem cells in the mammalian embryo depends on the POU transcription factor Oct4. Cell 95:379-391.

Nowak M and Hammerschmidt M. 2006. Ubc9 regulates mitosis and cell survival during zebrafish development. Mol Biol Cell 17:5324-5336.

Pangas SA, Choi Y, Ballow DJ, Zhao Y, Westphal H, Matzuk MM, Rajkovic A. 2006. Oogenesis requires germ cell-specific transcriptional regulators Sohlh1 and Lhx8 Proc. Natl. Acad. Sci 103(21): 8090 - 8095. 
Pichler A, Gast A, Seeler JS, Dejean A, Melchior F. 2002. The nucleoporin RanBP2 is a SUMO1 E3 Ligase. Cell 108:109-20.

Prioleau MN, Huet J, Sentenac A, Mechali M. 1994. Competition between chromatin and transcription complex assembly regulates gene expression during early development. Cell 77(3): 439-49.

Saitoh H and Hinchey J. 2000. Functional heterogeneity of small ubiquitin-related protein modifiers SUMO-1 versus SUMO-2/3. JBC 275(9): 6252-6258.

Schier AF. 2007. The maternal-zygotic transition: death and birth of RNAs. Science 316(5823): 406-407.

Shao R, Zhang FP, Rung E, Palvimo JJ, Huhtaniemi I, Bilig H. 2004. Inhibition of small ubiquitin-related modifier-1 expression by luteinizing hormone receptor stimulation is linked to induction of progesterone receptor during ovulation in mouse granulosa cells. Endocrinology 145:384-392

Shermoen AW and O'Farrell PH. 1991. Progression of the cell cycle through mitosis leads to abortion of nascent transcripts. Cell 67(2): 303-10.

Shin EJ, Shin HM, Nam E, Kim WS, Kim J-H, Oh B-H, Yun Y. 2012. DeSUMOylating isopeptidase: a second class of SUMO protease. EMBO Rep 13:339-46.

Soyal SM, Amleh A, Dean J. 2000. FIGalpha, a germ cell-specific transcription factor required for ovarian follicle formation. Development 127(21):4645-4654.

Speicher MC, Antonarakis SE, Motulsky AG. 2009. Vogel and Motulsky's Human Genetics: Problems and Approaches (4th ed.). Springer p. 422.

Tadros W and Lipshitz HD. 2005. Setting the stage for development: mRNA translation and stability during ooccyte maturation and egg activation in Drosophila .Dev Dyn 232(3): 593-608.

Tadros W and Lipshitz HD. 2009. The maternal-to-zygotic transition: a play in two acts. Development 136: 3033-3042.

Tatham MH, Jaffray E, Vaughan OA, Desterro JM, Botting CH, Naismith JH, Hay RT. 2001. Polymeric chains of SUMO-2 and SUMO-3 are conjugated to protein substrates by SAE1/SAE2 and Ubc9. J Biol Chem 276(38): 35368-74.

Thorgaard GH, Bailey GS, Williams D, Buhler DR, Kaattari SL, Ristow SS, Hansen JD, Winton JR, Bartholomew JL, Nagler JJ, Walsh PJ, Vijayan MM, Devlin RH, Hardy RW, Overturf KE, 
Young WP, Robison BD, Rexroad C, Palti Y. 2002. Status and opportunities for genomics research with rainbow trout. Comp Biochem Physiol B Biochem Mol Biol 133(4): 609-46.

Tong ZB, Gold L, Pfeifer KE, Dorward H, Lee E, Bondy CA, Dean J, Nelson LM. 2000. Mater, a maternal effect gene required for early embryonic development in mice. Nature genet 26(3):267-268.

Trinkaus JP. 1984. Mechanims of fundulus epiboly: a current view. American Zoologist. Oxford University Press 24(3): 673-688.

Tripurani KS, Lee BK, Smith WG, Yao J. 2010. Cloning and expression of bovine factor in the germline alpha (FIGLA) in oocytes and early embryos: a potential target of microrna-212. Reprod Fertil Dev 23(1):109-9.

Tyler CR and Sumpter JP. 1996. Oocyte growth and development in teleosts. Rev Fish Biol Fish 6(3):287 - 318.

Uzbekova S, Roy-Sabau M, Dalbies-Tran R, Perreau C, Papillier P, Mompart F, Thelie A, Pennetier S, Cognie J, Cadoret V, Royere D, Monget P, and Mermillod P. 2006. Zygote arrest 1 gene in pig, cattle and human: evidence of different transcript variants in male and female germ cells. Reprod Biol Endocrinol 4(1):12.

Wang ZB, Ou XH, Tong JS, Li S, Wei L, Ouyang YC, Hou Y, Schatten H, Sun QY, 2010. The SUMO pathway functions in mouse oocyte maturation. Cell Cycle 9(13):2640-6.

Wei F, Schöler HR, and Atchison ML. 2007. Sumoylation of Oct4 Enhances Its Stability, DNA Binding, and TransactivationJ. Biol. Chem. 282(29): 21551-21560.

Wu X, Viveiros MM, Eppig JJ, Bai Y, Fitzpatrick SL, Matzuk MM. 2003. Zygote arrest 1 (Zar1) is a novel maternal-effect gene critical for the oocyte-to-embryo transition. Nature genet 33(2):187-191.

Wu Y, Guo Z, Wang X, Yang L, Shi X, Du J, Tang B, Li W, Yang L, Zhang Y. 2012. SUMOylation represses Nanog expression via modulating transcription factors Oct4 and Sox 2. PLoS One 7(6):e39606.

Yan C, Wang P, DeMayo J, DeMayo FJ, Elvin JA, Carino C, Prasad SV, Skinner SS, Dunbar BS, Dube JL, Celeste AJ, Matzuk MM. 2001. Synergistic roles of bone morphogenetic protein 15 and growth differentiation factor 9 in ovarian function. Mol Endocrinol 15(6):854-866.

Yu B, Shao Y, Zhang C, Chen Y, Zhong Q, Zhang J, Yang H, Zhang W, Wan J. 2009. BS69 undergoes SUMO modification and plays an inhibitory role in muscle and neuronal differentiation. Exp cell res 315(20): 3543-3553. 
Yuan H, Zhou J, Deng M, Liu X, Le Bras M, de The Hm Chen SJ Chen Z, Liu TX, Zhu J. 2010. Small ubiquitin-related modifier paralogs are indispensable but functionally redundant during early development of zebrafish. Cell Res 20:185-196.

Zheng P and Dean J. 2007. Oocyte-specific genes affect folliculogenesis, fertilization, and early development. Semin reprod med 25(4):243-251. 